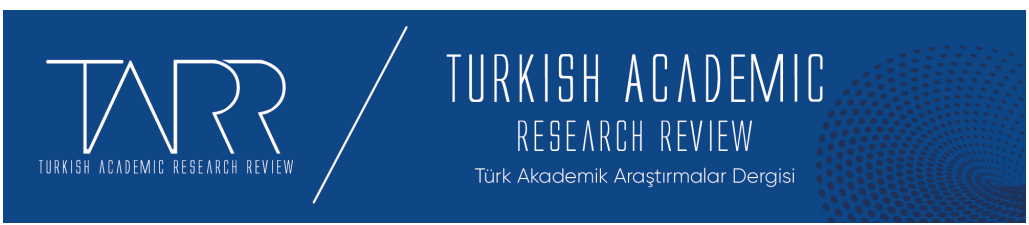

e-ISSN: 2602-2923

Yıl/Year: 2021

Cilt/Volume: 6 Sayı/Issue: 1

\title{
Mezhebî Aidiyetler Bağlamında Mu'tezile’nin Arap Dilini Kullanımı
}

The Usage Of The Arabic Language By Mu'tezila In Context Of Sectarian Relations

\section{Turan BAHŞİ}

Dr. Arş. Gör., Akdeniz Üniversitesi İlahiyat Fakültesi, Antalya, turanbahsi@akdeniz.edu.tr, Orcid ID: orcid.org/0000-0003-0900-9258.

\begin{tabular}{r|l} 
Makale Bilgisi & Article Information \\
Makale Türü - Article Type & Araştırma Makalesi / Research Article \\
Geliş Tarihi - Date Received & 29 Ocak / January 2021 \\
Kabul Tarihi - Date Accepted & 22 Mart / March 2021 \\
Yayın Tarihi - Date Published & 25 Mart / March 2021 \\
Yayın Sezonu & Ocak - Şubat - Mart \\
Pub Date Season & January - February - March
\end{tabular}

Atıf / Cite as: Bahşi, Turan, Mezhebî Aidiyetler Bağlamında Mu'tezile'nin Arap Dilini Kullanımi/ The Usage Of The Arabic Language By Mu'tezila In Context Of Sectarian Relations. tarr: Turkish Academic Research Review, 6 (1), 253-292. doi: 10.30622 tarr.870752

Íntihal / Plagiarism: Bu makale, en az iki hakem tarafından incelenmiş ve intihal içermediği teyit edilmiştir. / This article has been reviewed by at least two referees and confirmed to include no plagiarism. https://dergipark.org.tr/tr/pub/tarr

Copyright (C) Published by Mehmet ŞAHIN Since 2016- Akdeniz University, Faculty of Theology, Antalya, 07058 Turkey. All rights reserved.

Turkish Academic Research Review - Türk Akademik Araştırmalar Dergisi 


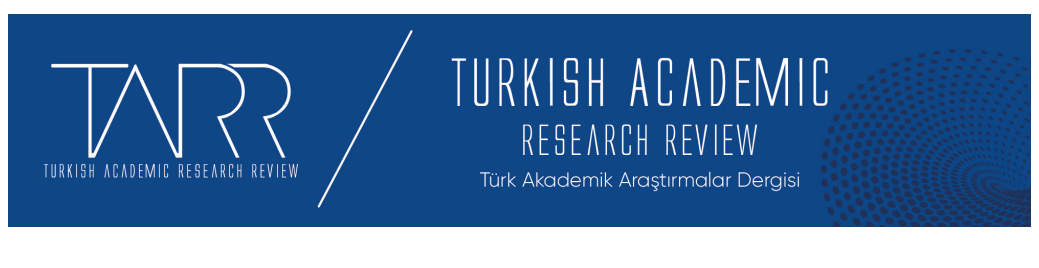

e-ISSN: 2602-2923 Yil/Year: $2021 \quad$ Cilt/Volume: 6 Sayı/Issue: 1

\section{Mezhebî Aidiyetler Bağlamında Mu'tezile’nin Arap Dilini Kullanımı ${ }^{1}$}

\section{Turan Bahşi}

\section{Özet}

İslâm düşünce tarihinde Mu'tezile, kendine has akılcı söylemleriyle temâyüz eden itikadî bir mezheptir. Söz konusu ekol mensupları, inanç sistemlerini "usûl-i hamse" adını verdikleri beş temel esas üzerine kurmuşlardır. Onlar Kur'ân'ın sözü edilen prensipler doğrultusunda anlaşılması gerektiğgini savunmuşlar ve zâhirî anlamı bu esaslarla çelişen âyetleri, mezhebî fikirlerine uyumlu hale getirmek için kimi zaman Arap diline dayalı olarak tevile yönelmişlerdir. Bu makale $\mathrm{Mu}$ 'tezile mensuplarının, dile ait verileri mezhebî fikirlerini destekleyecek şekilde kullanımlarını Arap dili perspektifinden değerlendirmeyi amaçlamaktadır. Bu nedenle çalışmamız Kelâm ve Tefsir ilimlerinin Arap dili orjininde buluştuğu disiplinler arası bir araştırma özelliği taşımaktadır. Çalışmada nitel araştırma tekniklerinden döküman analizi metodu esas alınmıştır. Makalede öncelikle mezhep mensuplarının dille irtibat kurduğu alanlar genel hatlarıyla incelenmiş, ardından i'tizâlî fikirler doğrultusunda kullanılan Arap diline ait veriler, gramatik tahliller ve belâgî yorumlar başlıkları altında analize tabi tutulmuştur. Ayrıca Mu'tezile'nin mezhebî sâiklerle kullandığı kıraat farklılıkları da dilsel zeminde tartışılmıştır. Mezhep mensuplarının, itikadî fikirleri doğrultusunda yaptıkları gramatik izahlar genellikle âyetlerin farklı i'râb çözümlemelerine dayanmaktadır. Onlar, âyetlerin anlamlarını mezhebî fikirlerine göre sabitleyip i'râb çözümlemelerini bu doğrultuda yapmışlardır. Bununla birlikte bazı harflere ideolojilerine uygun anlamlar yükledikleri tespit edilmiştir. Mu'tezile için belâgata dair veriler ise mezhebî fikirlerin ortaya konulması açısından önemli görülmüştür. Mezhep mensuplarının itikadî aidiyetleri bağlamında kullandıkları en temel belagat unsuru mecâzdır. Arap dilinde mecâz, Mu'tezilî düşünürlerin elinde bir yandan dilsel olarak sınırları çizilen bir kavram halini almış diğer yandan i'tizâlî düşüncede kullanılan bir yorum aracına dönüşmüştür. Mezhep mensupları gerek nahvî gerek belâgî izahlarda olsun Arap dilini, usûl-i hamseye hizmet edecek şekilde kullanmışlardır. $\mathrm{Bu}$ durum onların eserlerinde yer verdikleri kimi dilsel tahlilleri, nastan hareketle düşünceyi inşa etmek gibi bir gaye ile yapmadıklarını bunun yerine

${ }^{1}$ Bu makale Mu 'tezilî Düşüncenin Temellendirilmesinde Arap Dilinin Rolü (Keşşâf Örneği) başlıklı doktora tezinden üretilmiştir.

Turkish Academic Research Review - Türk Akademik Araştırmalar Dergisi 
söz konusu dilsel analizleri ideolojik amaçlarla kullandıklarını ortaya koymaktadır. Çalışmamızın Mu'tezilî gelenekteki dil ve düşünce arasındaki ilişkinin sorgulanmasına katkı sunması öngörülmektedir.

Anahtar Kelimeler: Arap Dili, Mu`tezile, Dil-Düşünce İlişkisi, Nahiv, Belâgat.

\section{The Usage Of The Arabic Language By Mu'tezila In Context Of Sectarian Relations}

\section{Abstract}

The Mu'tazila is a school of theology which became distinguished in the history of Islamic thinking by its peculiar rational expressions. The members of this school being talked of, defended that the Qor'an has to be understood in the direction of the fundamental principles named usul al-khams. They sometimes tend to interpret the apparent meanings based on the Arabic language to get verses that contradict to these principles matched with their sectional thoughts. In this article there is intended to evaluate the usage of language data by Mu'tezilian members in a way that supports their sectarian thoughts from the Arabic language perspective. For this reason, our study has the feature of an interdisciplinary research in which the sciences of Kalam and Tafsir meet in the origin of the Arabic language. In this study the document analysis method, one of the qualitative research techniques, was used. In this article firstly the areas where members of the sect communicate with language were examined in general terms, and then the data belonging to the Arabic language used in line with the ideas of the sect were analyzed under the headings of grammatical analyzes and eloquent comments. In addition, the differences in the

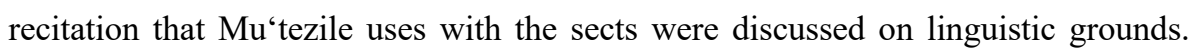
The mentioned situation sometimes caused them to move away from the context of the verse due to different i'râb evaluations. However, we witness that they load appropriate meanings to the letters in line with their ideology. In the grammatical explanations mentioned, Mu'tazila sometimes took advantage of the opportunities of the Arabic language, and sometimes has resorted to some strained interpretations that is not inherent in the language. For Mu'tazila, the data on rhetoric are considered important in terms of revealing the theological ideas. The most basic element of rhetoric used by the members of the creed in the context of their theological affiliation is metaphor. Metaphor, in the Arabic language, has become a linguistically demarcated concept in the hands of Mu'tazilian philosophers, on the other hand, it has become a tool of interpretation used in ideological ideas. The 
members of the creed regarded the Arabic language as a tool serving the usûl-i hamse, both in nahvî and rhetoric explanations. This situation reveals that they did not make some linguistic analyzes they included in their works with the aim of establishing thought based on verses, instead they used these linguistic analyzes for ideological purposes. It is foreseen that our study will contribute to the questioning of the relationship between language and thought in the Mu'tezilian tradition.

Keywords: Arabic Language, Mu'tazila, The Relation Of Language And Thought, Grammar, Eloquence-Rhetoric.

\section{Structured Abstract}

$\mathrm{Mu}$ 'tazila is a school of Islamic theology that come to fore with its own rational discourse. The members of the school in question have built their belief systems on five basic principles which they call usul al-khams. They understood the Quranic verses in line with these principles that form the basis of their belief system and juggled with the verses that contradict these principles by using some mental methods. These alternative forms of verses include the use of Arabic language as an instrument of interpretation by the members of the school. They had a creed purpose such as having their "i "tizâlî" ideas approved by the Quran through linguistic references. This study aims to evaluate the use of language data by the members of $\mathrm{Mu}$ 'tazila in a way to support their creed ideas from the perspective of the Arabic language. For this reason, our study has the feature of an interdisciplinary research in which the sciences of Kalam and Tafsir meet in the origin of the Arabic language. The document analysis method, one of the qualitative research techniques, was used in the study. First of all, the areas where members of the creed communicate with language are examined in general terms. In the interpretation activities of Mu'tazila's verses based on linguistic data, the participation of the notables of the school since the emergence of the creed, who are interested in language and literature and conducting studies in this field, has a great role. In fact, having a linguist identity and being interested in language studies can be considered as one of their most distinctive qualities. Members of Mu'tazila used their knowledge and experience in the field of Arabic language to support their theological preferences in the debates they are involved. According to Mu'tazila, an interpreter should use his knowledge and experience in the field of language, as in other religious sciences, to serve the principles of monotheism and divine justice, which are accepted as the summary of the five basic principles of the creed. In the interpretation made by the members of

Turkish Academic Research Review - Türk Akademik Araştırmalar Dergisi 
the sect, the Arabic language is considered to be important as it serves the "usûl-i hamse". In fact, the Arabic language for Mu'tazila is a mechanism that comes into play in expressing the previously adopted ideology, but not in the formation of the "i 'tizâlı”" idea. In our study, the data of the Arabic language, which were determined to be used by the members of the creed in line with the i'tizâlî ideas, were analyzed under the headings of grammatical analysis and rhetoric comments. The grammatical explanations used by the members of the creed in the context of their theological affiliation are generally based on different "i 'râb" analyzes of the verses. They fixed the meanings of the verses according to their creed ideas and made their analysis in this direction. The mentioned situation sometimes caused them to move away from the context of the verse due to different i'râb evaluations. However, we witness that they load appropriate meanings to the letters in line with their ideology. In the grammatical explanations mentioned, Mu'tazila sometimes took advantage of the opportunities of the Arabic language, and sometimes has resorted to some strained interpretations that is not inherent in the language. For $\mathrm{Mu}$ 'tazila, the data on rhetoric are considered important in terms of revealing the theological ideas. Namely, the success of the members of the creed in their discussions is closely related to their ability to use their "nice and effective speech" skills. The most basic element of rhetoric used by the members of the creed in the context of their theological affiliation is metaphor. Metaphor, in the Arabic language, has become a

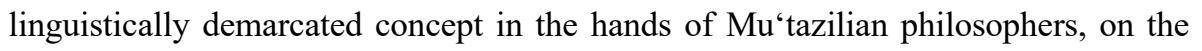
other hand, it has become a tool of interpretation used in ideological ideas. Namely, while the verses that comply with the basic principles of the creed are accepted as muhkem and understood in their real meaning; The verses that are contrary to the aforementioned principles were regarded as mutaşâbih and were taken out of their true meanings in line with the verses that were accepted as muhkem on the same subject, and were transferred to metaphorical meanings. The point that draws attention here is that they show their theological prejudices as "presumption" in the verses that they do not consider rational to understand the real meaning and interpreting the mentioned expressions as metaphorical. They have benefited from metaphor in a way to support their theological ideas on the issues mentioned. It is seen that members of Mu'tazila, who stand out with their linguist identity, are also interested in the field of recitation. They took into account the structure of recitations that allowed different linguistic inferences and benefited from this point as long as they supported their creed ideas. The members of the creed regarded the Arabic language as a tool serving the usûl-i hamse, both in nahvî and rhetoric explanations. This situation reveals that they did not make some linguistic analyzes 
they included in their works with the aim of establishing thought based on verses, instead they used these linguistic analyzes for ideological purposes. We consider that this study will contribute to the questioning of the relationship between

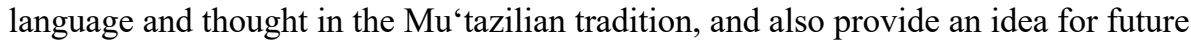
studies where the mentioned relationship will be analyzed and discussed.

\section{Giriş}

Son ilâhî mesaj olan Kur'ân, insanlığa Arapça olarak gönderilmiştir. ${ }^{2}$ İslâm düşünce tarihinde Arap dili, farklı etnik kökene sahip Müslümanlar arasında müşterek manevî kültürü yansıtan bir boyut kazanmış ve "din dili" olarak telakki edilmiştir. ${ }^{3}$ Zira vahyin Arapça oluşu, dinî bilgi ve bu dil arasında bir ilişkinin tesis edilmesini gerekli kılmıştır. Söz konusu ilişki gözetilerek âyetlerin izahında dilsel referanslardan istifade edilmiştir. Öte yandan dil kurallarıyla bağdaşmayan, diğer bir ifadeyle Arap dilinin onaylamadığı tevillerin ise muteber kabul edilemeyeceği de belirtilmiştir. ${ }^{4}$ Yorum faaliyetlerinde dilsel argümanlara yer verenlerden biri de Mu'tezile mezhebidir.

Mu'tezile, hicrî ikinci asrın başlarında tarih sahnesine çıkan ve ortaya koyduğu kendine has akılcı söylemleriyle temâyüz eden itikadî bir mezheptir. ${ }^{5}$ Mezhep mensupları inanç sistemlerini "usûl-i hamse" adını verdikleri beş temel prensip üzerine inşa etmişlerdir. Bu esaslar; tevhid, adalet, va'd ve va`îd, el-menzile beyne'l-menzileteyn ve el-emru bi'l-ma'rûf ve'n-nehyu 'ani'l-münkerdir. Onlar inanç esaslarının beş esas şeklinde formüle edilmesinin, kendilerini diğer itikadî ekollerden ayırt eden bir yönü olduğuna dikkat çekerek ${ }^{6}$ usûl-i hamse'yi bir bütün olarak benimsemeyen kişinin Mu 'tezilî kabul edilemeyeceğini vurgulamışlardır. ${ }^{7}$

Mu'tezile mensupları temel inanç prensiplerini temsil eden usûl-i hamseye uygun olan âyetleri, olduğu gibi kabul ederlerken; zâhirî anlamı bu

2 Ahkâf 46/12; Yûsuf 12/2; Zümer 39/28; Nahl 16/103; Ra'd 13/37.

${ }^{3}$ Ignaz Goldziher, Klasik Arap Literatürü, (çev. Rahmi Er-Azmi Yüksel), Vadi Yayınları, Ankara 2012, s. 18.

${ }^{4}$ Yusuf Işıcık, Kur'ân'ı Anlamada Temel İlkeler, Esra Yayınları, Ankara 1997, s. 103.

5 Osman Aydınlı, Doğuşundan Büyük Selçuklulara Mu'tezile Ekolü, Doğuşundan Büyük Selçuklulara Mu'tezile Ekolü: Tarihi ve Öğretisi, Endülüs Yayınları, İstanbul 2018, s. 239240.

6 Kâdî Abdülcebbâr, Ebu'l-Hasen b. Ahmed el-Hemedânî, Şerhu'l-usûli'l-hamse, thk. Abdulkerim Osman, Mektebetü Vehbe, Kahire 1996, s. 123-124.

${ }^{7}$ Hayyât, Ebu'l-Hüseyn Abdürrahîm b. Muhammed b. Osmân, Kitâbu'l-intisâr ve'r-reddi 'alâ İbni'r-Râvendî el-mulhid, nşr. H. Samuel Nyberg, Mektebetü'd-Dâri'l-Arabiyye, Beyrut 1993, s. 126-127.

Turkish Academic Research Review - Türk Akademik Araştırmalar Dergisi 
esaslarla çelişen âyetleri mezhebî fikirlerine uyumlu hale getirmek için te'vil etmişlerdir. Bu nedenle Mu’tezile'nin diğer itikadî mezheplerle teolojik gerilimi en yoğun yaşadığı yer, hiç şüphesiz Kur'ân'nın anlaşılması konusudur. Onlar, Kur'ân'ın dinî bilgi için temel referans olma özelliğini, mezhebî gerekçelerle kullanarak kendi fikirlerini Kur'ân'a onaylatma çabası içerisine girmişlerdir. Bu hususta onların gâibin şâhide kıyası, müteşâbihin muhkeme hamli ve aklın nakle tahkimi gibi birtakım yöntemler izledikleri ifade edilmektedir. ${ }^{8}$ Bahsedilen metotlar uygulanış bakımından Mu'tezile'nin, âyetlerin dilsel analiziyle yakından ilgilenmesini de gerekli kılmıştır. Nitekim mezhep mensupları, usûl-i hamse çerçevesinde ileri sürdükleri itikadî fikirleri dil-düşünce zemininde kurgulamaya gayret etmişler ve dilbilimine dair verileri, sahip oldukları itikadî düşünceleri Kur'ân'a dayandırmak maksadıyla istihdam etmişlerdir.

$\mathrm{Bu}$ makale $\mathrm{Mu}$ 'tezile mensuplarının dile ait verileri itikadî fikirlerinin destekleyicisi olarak kullanımların Arap dili perspektifinden değerlendirmeyi amaçlamaktadır. Bu nedenle çalışmamız Kelâm ve Tefsir ilimlerinin Arap dili orjininde buluştuğu disiplinler arası bir araştırma özelliği taşımaktadır. Araştırmada başta Zemahşerî (ö. 538/1144) olmak üzere İbn Cinnî (ö. 392/1002) ve Kâdî Abdülcebbâr (ö. 415/1025) gibi Mu'tezilî müelliflerin eserlerinden döküman analizi metoduyla elde edilen bulgular dilsel zeminde tartışılmıştır. Söz konusu dilsel argümanlardan önce Mu'tezile'nin Arap diliyle ilgilenmesinin ardında yatan hususlar genel hatlarıla ele alınacaktır.

\section{Mu'tezile'nin Arap Dilini Kullanmasının Arka Planı}

Mezhep mensuplarının dille irtibatı incelendiğinde onların kelâmcı kimliklerinin yanı sıra Arap dili alanında yürütülen çalışmalara da katıldıkları görülmektedir. Onlar dil alanında edindikleri bilgileri girdikleri münazaralarda ve beytü'l-hikme'de gerçekleştirilen tercüme faaliyetlerinde kullanmışlardır. Mezhebî âidiyetler bağlamında yararlandıkları dilsel argümanlara geçmeden önce sözü edilen hususlar genel hatlarıla ele alınacaktır.

\subsection{Dilci Kimlikleri}

Mu'tezile'nin, âyetlerin dilbilim verilerine dayalı bir şekilde te'vil çabalarında, ortaya çıkışından itibaren mezhebin ileri gelenlerinin dil ve edebiyata merak duyan ve bu alanda çalışmalar yürüten kişilerden oluşmasının rolü büyüktür. Kaynaklarda Mu‘tezile'nin kurucu imamlarından Vâsıl b. Ata'nın (ö. 131/748)

${ }^{8}$ Sözü edilen metotlarla ilgili detaylı bilgi için bkz. Yasin Pişgin, Kur'an'da Akıl ve Tefsirde Akılcılık, İlâhiyât Yayınları, Ankara 2015, s. 191-203. 
Arapça'da "garîb" kelimelerin anlamlarını bile çok iyi bildiği ve bu kelimeleri özenle kullandığı bilgisi bulunmaktadır. Öyle ki onun, içinde “ر” (r) harfi bulunan kelimeleri doğru bir şekilde telaffuz edemediği ve bu harfin bulunmadığı eş anlamlı kelimeleri ustalıkla seçmesi sayesinde konuşurken hiç sıkıntı yaşamadığı da söylenmektedir. Fahreddin er-Râzî (ö. 606/1210) Vâsıl’ın “mızrağını at!” ve “atına

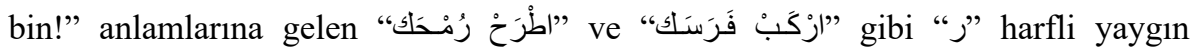

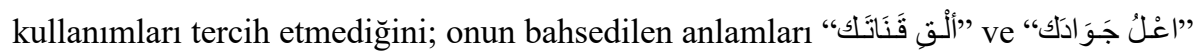
sözleriyle ifade ettiğini söylemektedir. ${ }^{9}$ Hatta dönemin Irak valisinin huzurunda Vâsıl'ın “ر” harfli kelimeleri kullanmadan bir hutbe verdiği ve onun ", harfini telaffuz etmeden meramını kolaylıkla anlatabilmesinin Arap edebiyatında

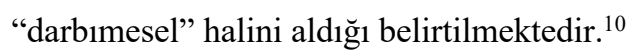

Mu'tezile mezhebinin ortaya çıkışında önemli rol oynayan Basralı Amr b. Ubeyd'in (ö. 144/761) ise dil sahasında uzman bir kişi olduğu; özellikle edebî sanatları kullanımındaki mahareti sayesinde muhataplarını etkilediği ve fikirlerini toplumda rahatlıkla yayabildiği dile getirilmektedir. ${ }^{11}$ Diğer bir Mu'tezilî Bişr b. Mu'temir (ö. 210/825) ise şiir ve edebiyat konusundaki bilgisiyle meşhur olmuştur. Genellikle didaktik türde şiirler kaleme almasının yanı sıra onun Câhiliyye şiirlerine de vâkıf olduğu görülmektedir. Bu hususta Câhız, mezhep mensupları arasında Bişr'in şiir rivâyeti hususundaki özel konumunu "Tüm Mu'tezilî âlimler, Arap şiirini nakletmekle ilgilenmişlerdir. Ancak onların şiir rivayetiyle en çok ilgileneni, Bişr'dir." sözleriyle ifade etmektedir. ${ }^{12}$ Şiir konusundaki çalışmalarına ek olarak Bişr'in Sâhîfetü'l-belâğa isimli risâlesi belâgatın teorik yönüne ilişkin erken dönem dil çalışmalarından biri olarak görülmektedir. ${ }^{13} \mathrm{O}$, sözü edilen eserde lafız ve anlam

9 Râzî, Ebû Abdillâh (Ebu'l-Fazl) Fahrüddîn Muhammed b. Ömer, Nihâyetü'l-îcâz fî dirâyeti'l-i 'câz, thk. Nasrullah Hacımüftüoğlu, Dâru Sâdır, Beyrut 2004, s. 55. Zemahşerî'nin, Vâsıl'ın " $\jmath$ " harfli kelimeleri telaffuz edememesinden Divân isimli eserinde bahsettiği görülmektedir. O, döneminin yöneticilerinin önemli makamlara yaptıkları atamalarda kendisine de görev vermelerini dileyerek şöyle demektedir:

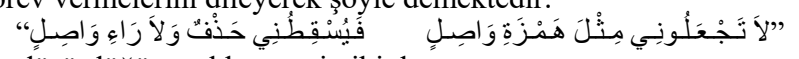

"Bana ne hazfin düşürdüğü vasıl hemzesi gibi davranın.

Ne de Vâsıl'ın (telaffuz edemediği) "râ" harfi gibi davranın." (Zemahşerî, Ebu'l-Kâsım Mahmûd b. Ömer, Dîvânu Cârillâh ez-Zemahșerî, Dâru Sâdır, Beyrut 2008, s. 503.)

10 İsmail Durmuş, "Hazif", TDV İslâm Ansiklopedisi, İstanbul 1998, c. XVII, s. 124.

${ }^{11}$ Kâdî Abdülcebbâr, Serhu'l-usûli'l-hamse, s. 588; Johann Fück, el- 'Arabiyye -dirâsâtun fi'lluğa ve'l-lehecât ve'l-esâlîb-, (çev. Abdulhalim en-Neccâr), Mektebetü'l-Hancî, Kahire 1952, s. 59.

${ }^{12}$ Câhız, Ebû Osmân Amr b. Bahr b. Mahbûb el-Kinânî, Kitâbu'l-hayevân, thk. Abdüsselâm Muhammed Harun, yy. 1965. c. VI, s. 405.

13 Bişr, İbrâhim. b. Cebele b. Mahreme es-Sekunî, öğrencilerine hitâbet dersi anlatırken yanlarına gitmiş. Bunun üzerine İbrâhim, Bişr'in dersine katılmak istediğini sanmıştır. Ne var ki Bişr, İbrâhim'in öğrencilerine yönelerek "Siz İbrâhim'in anlattıklarını dikkate almayın!" dedikten sonra belâgatle ilgili tuttuğu notları onlara vermiștir. Bkz. Câhız, Ebû Osmân Amr b. Bahr b. Mahbûb el-Kinânî, el-Beyân ve't-Tebyîn, thk. Abdusselam Muhammed Harun, yy.

Turkish Academic Research Review - Türk Akademik Araştırmalar Dergisi 
arasındaki bağ, bir lafzın fasih olarak değerlendirilmesi için aranılan şartlar ve sözdeki ta'kid (kapalılık) gibi unsurları genel hatlarıla ele alarak; kendisinden sonraki dilcilerin belâgatı, teorik olarak incelemelerinin yolunu açmıştır. ${ }^{14}$ Mu'tezile'nin itikadî bir mezhep haline gelmesinde etkin bir rol oynayan Ebu'lHuzeyl el-Allâf'ın (ö. 235/849) da dil ve edebiyat konularına ilgi duyan bir kişi olduğu görülmektedir. Öyle ki Arap edebiyatının ileri gelen simalarından Müberred'in (ö. 286/900) Ebu'l-Huzeyl'in edebî yönünü övdüğüne ve onu fesâhat sahibi bir kişi olarak betimlediğine dair birtakım rivâyetler aktarılmaktadır. ${ }^{15}$

İlk dönem Mu'tezile imamları tarafından Arap diline gösterilen ilgi sonraki kuşaklar tarafından da sürdürülmüştür. Onların arasında da Arap dil çalışmalarında ön saflarda bulunan ve itikadî düşüncenin Arap diliyle bağlantısını ortaya çıkarmaya çalışan isimlerle karşılaşılmaktadır. Bir örnek vermek gerekirse Mu'tezilî İbn Cinnî (ö. 392/1002) Arap dilinin usûlünü incelediği el-Hasâis isimli kitabının “Arap dilinin, dinî inancı korumasının bâbı" başlığını taşıyan kısmın, eserinin en kıymetli bölümlerinden biri olduğu söylemekte ve burada dinî düşünce ve Arap dili arasında kuvvetli bir ilişki olduğunu vurgulamaktadır. İbn Cinnî, dinî düşüncede pekçok kişinin doğru yoldan ayrılıp dalâlete düşmesinin onların Arap dilini yeterince bilmemesinden kaynaklandığını vurgulamaktadır. ${ }^{16}$

Mu'tezile'nin son halkasında bulunan ve taassup derecesinde mezhebine bağlı olan ${ }^{17}$ Zemahşerî de yaptığı çalışmalar ile Arap diline katkı sunmuştur. O elMufassal isimli nahiv kitabında bu dile hizmet etmeyi kendisine nasip ettiği için Allah'a hamdetmektdir. ${ }^{18}$ Müellif sözü edilen eserinde fikıh ve tefsir gibi dinî disiplinlerin Arap dilinden bağımsız bir şekilde düşünülemeyeceğini söylemektedir.

tsz. c. I, s. 135; İbn Abdürabbih, Ebû Ömer Şihâbüddîn Ahmed, el-ikkdu'l-ferîd, thk. Abdulmecîd et-Terhînî, Dâru'l-Kütübi'l-i̇lmiyye, c. IV, s. 146-147.

${ }^{14}$ Velîd Kassâb, et-Türâsin-nakdî ve'l-belâğ̂̀ li'l-Mu'tezile hatta nihâyeti'l-karni's-sâdisi'lhicrî, Dârü's-Sekâfe, Katar-Doha 1985, s. 39-42.

15 Kassâb, et-Türâsin-nakdî ve'l-belâgî s. 35; Hasan Marulcu, Ehl-i Sünnet ve Mu'tezile Kelâmı Bağlamında Kelâm - Belâgat İlişkisi, Dilara Yayınları, Isparta 2012, s. 30.

16 İbn Cinnî, Ebu'l-Feth Osmân, el-Hasâis, thk. Muhammed Ali en-Neccâr, el-Mektebetü'lİlmiyye, yy. tsz. c. III, s. 245.

17 Zemahşerî’nin hayatı incelendiğinde onun yakaladığı her firsatta i'tizâlî kimliğini ön plana çıkarma gereği hisseden biri olduğuna tanık olunmaktadır. Nitekim kaynaklarda onun yakınlarını ziyarete gittiğinde kim olduğunu soran bir hizmetçiye "Ebu'l-Kâsım el-Mu'tezilî geldi, de!" şeklinde bir cevap verdiği rivâyet edilmektedir. Bkz. İbn Hallikân, Ebu'l-Abbâs Şemsüddîn, Vefeyâtu'l-a'yân ve enbâu ebnâi'z-zamân, thk. İhsan Abbas, Dâru Sâdır, Beyrut 1968, c. VII, s. 168, 170; Taşköprizâde, Ahmed b. Mustafa, Miftâhu's-sa 'âde ve misbâhu'ssiyâde fì mevzu 'âti'l- ‘ulûm, Dâru'l-Kütübi'l-İlmiyye, Beyrut 1985, c. II, s. 87; Suyûtî, Ebu'lFazl Celâlüddîn Abdurrahmân, Buğyetü'l-vu'ât fì tabakâti'l-luğaviyyîn ve'n-nuhât, thk. Muhammed Ebu'l-Fazl İbrâhîm, Dâru'l-Fikr, Beyrut 1979, c. II, s. 279.

18 Zemahşerî, Ebu'l-Kâsım Mahmûd b. Ömer, el-Mufassal fì 'ilmi'l-'Arabiyye, thk. Fahr Sâlih Kadâra, Ummân 2003, s. 29. 
Zemahşerî, fikıh usûlünün pek çok konusunun nahiv ilmine dayandığını ${ }^{19}$ bunun yanı sıra tefsirlerde de âyetlerin anlamlarını izah etmek için Sîbeveyhi (ö. 180/796), Kisâî (ö. 189/805), Ferrâ (ö. 207/822) ve Ahfeş (ö. 215/830) gibi dilcilere müracaat edildiğini ifade etmektedir. ${ }^{20}$ Zemahşerî nahiv ilminin yanında belâgatle de ilgilenmiştir. O Keş̧̧âf isimli tefsirini kaleme alırken kendinden önce temelleri Abdulkâhir el-Cürcânî (ö. 471/1078-79) tarafindan atılan "nazm" teorisinin uygulayıcısı olmuştur. ${ }^{21}$ Müellif Keşşâf' 'n girişinde belâgata dair bilgilerin tefsir ilmi açısından müstesnâ bir konumda bulunduğunu Câhız'ın (ö. 255/869) Nazmu'lKur'ân isimli eserinden yaptığı bir alıntıyla şöyle dile getirmektedir:

Bir fakîh, ahkâma ilişkin ilimlerde ve fetva verme hususunda akranları arasında öne çıkıp varlığını gösterse de bir mütekellim kelâm ilminde diğer insanların fevkinde olsa da kıssa ve haber ezberleyen biri İbnu'lKırriyye'den (ö. 84/703) daha çok bilgiye sahip olsa da bir vâiz Hasan-1 Basrî'den (ö. 110/728) daha etkileyici vaaz etse de bir nahivci Sîbeveyhî’den (ö. 180/796) daha iyi gramer kurallarını bilse de lugat ilmiyle meşgul olan biri tüm sözcükleri diline pelesenk etse de bahsedilen kişilerden hiçbiri Kur'ân'a özgü olan şu iki disiplinde yetkinleşmedikçe hakikat (denizine) dalamaz. Bunlar, ilmü'l-me‘ânî ve ilmü'l-beyân'dır. ${ }^{22}$

Verilen örneklerden de anlaşıldığı üzere mezhep mensupları arasında dilci kimliği ile ön plana çıkan pekçok isme rastlanmaktadır. Bu hususta dilci kimliğe sahip olmanın ve dil çalışmalarıyla ilgilenmenin onların en belirgin vasıflarından biri olduğu söylenelebilir. Onlar Arap dili alanında edindikleri bilgi ve tecrübelerini yaptıkları itikadî tartışmalarda da kullanmışlardır. $\mathrm{Bu}$ yönüyle söz konusu münazaraların onların Arap diline başvurmalarının arka planını yansıtan bir özelliği bulunmaktadır.

\subsection{Yaptıkları Münazaralar}

${ }^{19}$ Nahiv-fikıh usûlü arasındaki ilișki hakkında detaylı bilgi için bkz. Osman Güman, Nahiv ve Fıkıh Usûlü İlişkisi, İSAM Yayınları, Ankara 2017, s. 31-66.

${ }^{20}$ Zemahșerî, el-Mufassal, s. 30.

${ }^{21}$ Hasan Taşdelen, "Belâgat İlmi ve Tarihi", İslâm Medeniyetinde Dil İlimleri -Tarih ve Problemler-, edt. İsmail Güler, İSAM Yayınları, İstanbul 2015, s. 270.

22 Zemahşerî, Ebu'l-Kâsım Mahmûd b. Ömer, el-Keşşâf 'an hakâiki ğavâmidı't-tenzîl ve 'uyûni'l-ekâvîl fî̀ vucûhi't-te'vîl, thk. Muhammed Abdusselâm Șâhîn Dâru'l-Kütübi'l-ilmiyye, Beyrut 2015, c. I, s. 7. Arap dili ve edebiyatı alanında önemli çalışmalar gerçekleştiren son dönem araştırmacılarından Şevki Dayf, Zemahșerî'nin "beyân” tabirinin yanında "me ân̂̂" şeklinde bir kavram tercih etmesinin ardında müellifin i'tizâlî kimliğinin etkili olduğunu söylemektedir. Daha detaylı bilgi için bkz. Şevkî Dayf, el-Belâğa: Tetavvur ve Tarîh, Dâru'lMeârif, Kahire tsz., s. 221.

Turkish Academic Research Review - Türk Akademik Araştırmalar Dergisi 
Mu'tezile mensupları Arap diline dair verileri, girdikleri münazaralarda teolojik tercihlerini desteklemek üzere kullanmışlardır. Onların gerek Ehl-i Kitab'la gerekse diğer ekollerle yaptıkları tartışmalarda dilin özelliklerinden ve inceliklerinden istifade ettikleri görülmektedir. Örneğin Hristiyanlar "O ve ondan razıyım.", "Sevgili oğlum, budur.", "Sen, benim sevgili oğlumsun, senden razıyım.” gibi İncil ifadelerinden hareketle Hz. Îsâ'nın (as) Tanrı'nın oğlu olduğunu iddia etmişler ve ona Tanrı'nın hulûl ettiğine inanarak ulûhiyet isnat etmişlerdir. Onlar İnciller'de Hz. Îsâ (as) için kullanılan “oğlum” ifadesinin Kur'ân'da Allah'a izafe edilen "habîb", "halîl" ve "rûh" gibi kavramlara benzediğini iddia etmişlerdir. ${ }^{23}$

Mu'tezile'den Câhız (ö. 255/869) Hristiyanların bu iddialarının geçersiz olduğunu şu şekilde ortaya koymuştur. Câhız "habîb", "halîl" ve "rûh" gibi ifadelerin Kur'ân'da mecâzî olarak kullanıldığını ve mecâzın belirlenmesinde hakiki anlamla mecazi anlam arasındaki "alâka"nın önemli bir fonksiyon yerine getirdiğini söylemiştir. Örneğin Kur'ân'da Hz. İbrâhim (as) hakkında kullanılan "halîl”" ifadesinin, onun ateşe atılırken gösterdiği sabır ve teslimiyetten kaynaklandığını yoksa Hristiyanların iddia ettikleri gibi Hz. İbrâhim için ulûhiyetten bir payın verilmesi gibi bir durumun asla söz konusu olmadığını ifade etmiştir. Buna ek olarak Câhız, hakikî anlamı bir yana “ibn/oğul” ifadesinin mecâzî olarak dahi, Tanrı'ya isnat edilemeyeceğini söylemiştir. Çünkü bu şekilde bir kullanım Allah’ın yüceliğine aykırıdır. Nitekim "oğul” ifadesinde mecâzî anlamın varlığını iddia etmek, şefkat ve merhamet amaçlı “amca” ve "dayı" gibi ifadelerin de O'nun hakkında söylenilmesine kapı aralamaktadır. Zira insanlar kendi aralarında konuşurken akrabalık bağı bulunmasa dahi karşısındaki kişi hakkında söz konusu ifadeleri kullanmaktadırlar. Bundan hareketle Câhız, Allah'a isnat edilen bir ifadenin sadece dilsel kullanımını yeterli görmeyerek, aynı zamanda bu ifadenin sübûtu kat‘̂̂ bir nasta bulunmasının gerekliliğine dikkat çekmiştir. İncillerin ise sübûtunun kesinliğinden bahsetmek imkânsızdır. Zira İnciller bir dilden diğerine tercüme edilerek orjinalliğini yitirmiş ve tahrif edilmiştir. Dolayısıyla İncildeki ifadelerin hakikat mi ya da mecâz mı olduklarının belirlenmesi bundan hareketle de Tanrı için mümkün olan veya olmayan isim ve sıfatların tespit edilmesi mümkün değildir. Câhız'ın ortaya koyduğu bu fikirler daha sonra Mu'tezilî Ebû Ali el-Cübbâî (ö. 303/916) tarafından da benimsenmiştir. ${ }^{24}$ Değinilen konuda Kâdî Abdülcebbâr ise dinî nasların anlaşılmasında vahyin indiği dildeki hakikî ve mecâzî ifadelerin doğru

${ }^{23}$ Konu hakkında detaylı bilgi için bkz. Marulcu, Kelâm - Belâgat İlişkisi, s. 73-74.

${ }^{24}$ Câhız, Ebû Osmân Amr b. Bahr, el-Muhtâr fi'r-reddi 'ale'n-nasârâ, thk. Muhammed Abdullah Şerkâvî, Daru'l-Cîl, Beyrut 1991, s. 72-81; Marulcu, Kelâm-Belâgat İlişkisi, s. 74. 
tespit edilmesine dikkat çekerek bu hususun diğer dillere yapılan tercümelerde de dikkate alınması gerektiğini şöyle dile getirmektedir:

Diller bu konuda (hakikî ve mecâzî ifadeler bakımından) birbirinden farklı mahiyet göstermektedir. Bu nedenle deriz ki: Bir dilden başka bir dile tercüme yapan kimse öncelikle Allah Teâlâ hakkında kullanılması mümkün olan ifadeleri bilmelidir. Buna ek olarak O’nun için söylenilmesi aklen mümkün olmayan ifadelerin farkında olması ve her iki dildeki hakikat ve mecâz kullanımları konusunda bilgi sahibi olması gerekir. Zira bir lafız kimi zaman bir dilde hakikî manada kullanılabilirken öteki dilde mecâzî anlamda kullanılabilir. Dolayısıyla mecâzî olarak geçen ifadeleri, başka dile hakikî anlamda çeviren kişi hata yapmıştır. Söz konusu kitaplardaki (Kutsal Kitaplardaki) mecâzî ifadelerin durumu, Kur'ân'daki müteşâbih âyetlerin durumuna benzer. Malumdur ki; Kur'ân'1 Arapça'dan Farsça'ya tercüme eden birçok kişi bu hususta ya anlamı aklen idrak edememesi nedeniyle ya da dil konusunda yeterli bilgiye sahip olmadığı için hataya düşmektedir. ${ }^{25}$

Mu'tezilîler gayri müslimlerin yanı sıra diğer mezheplerle yaptıkları münazaralarda da fikirlerini ortaya koyarken dilsel argümanlar kullanmışlardır. Mesela Mu'tezile Allah'ın sıfatları konusunda teşbih ve tecsime düşen ve O'nun sıfatlarının insanın sıfatları gibi olduğunu söylemekten geri durmayan akımlara karşı tenzihçi bir yaklaşımla ilâhî sıfatları, zihnî kavramlar ve hükümler düzeyine indirgeyen bir anlayış ortaya koymuştur. ${ }^{26} \mathrm{Mu}$ 'tezilî düşünürler, Allah'a ilim ve kudret gibi masdâr formunda bulunan sıfatların isnat edilemeyeceği konusunda fikir birliği etmişlerdir. ${ }^{27}$ Onlara göre bu sıfatların Allah'a isnadı, O'nun dışında başka kadîm varlıkların kabulü (teaddüd-i kudemâ) demek olup; bu durum tevhid fikrine aykırıdır. Bu hususta Vâsıl b. Ata "Kim Allah'a kadîm bir sıfat isnadında bulunursa, o kişi aslında iki ilâhın varlığını kabul etmişsir." demektedir. ${ }^{28}$ Teaddüd-i kudemâ

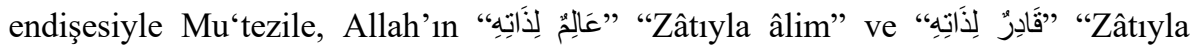
kâdir” olduğunu söyleyerek O’nun hakkında söz konusu sıfatların müştâk formlarının kullanılması gerektiğini ileri sürmüşlerdir. Hatta onlardan bazıları,

${ }^{25}$ Kâdî Abdülcebbâr, Ebu'l-Hasen b. Ahmed el-Hemedânî, el-Muğnî fì ebvâbi 't-tevhîd ve'l'adl, nşr. Emin el-Hûlî, Kahire 1960, c. V, s. 111.

26 Pişgin, Kur'ân'da Akll ve Tefsirde Akllculık, s. 183; İlyas Çelebi, "Sıfat", TDV İslâm Ansiklopedisi, İstanbul 2009, c. XXXVII, s. 101.

27 Râzî, Ebû Abdillâh (Ebu'l-Fazl) Fahrüddîn Muhammed b. Ömer, I'tikâdâtu firaki'lmüslimîn ve 'l-müşrikîn, nşr. Alî Sâmî en-Neşşâr, Dâru'l-Kütübi'l-İlmiyye, Beyrut 1982 s. 38 .

28 Şehristânî, Ebu'l-Feth Tâcüddîn (Lisânüddîn) Muhammed b. Abdilkerîm, el-Milel ve'nnihal, nşr. Ahmed Fehmî Muhammed Bağdâdî, Dâru'l-Kütübi'l-İlmiyye, Beyrut 1992, s. 38, 40.

Turkish Academic Research Review - Türk Akademik Araştırmalar Dergisi 
müştâk halde bulunan sıfatların da mecâzî mana taşıdığını iddia ederek Allah'ın her şeyi işitmesi ve görmesinin aslında her şeyi bilmesinden mecâz olduğunu söylemişlerdir. ${ }^{29} \mathrm{Bu}$ nedenle naslarda geçen sarîh ifadeleri i'tizâlî fikirleri doğrultusunda dilsel analizler yaparak yorumlamışlardır.

Görülüyor ki mezhep mensupları girdikleri tartışmalarda sahip oldukları dilsel birikimden istifade etmişlerdir. Bununla birlikte onlar dilci kimlikleriyle beytülhikme çatısı altında yürütülen faaliyetlere de katılmışlardır.

\subsection{Beytülhikme Faaliyetleri}

Beytülhikme, fetih hareketleriyle birlikte ilk kez tanışllan Helen, İran ve Hint gibi kültürlerin tanınması amacıyla felsefe ağırlıklı olmak üzere mantık, matematik, astronomi ve tıp gibi alanlarda pekçok eserin Arapça'ya tercüme edildiği bir kurumdur. Sözü edilen tercüme merkezleri aynı zamanda kültürlerde ortaya atılan dinî söylemlerin tahlil ve tenkit edildiği bir yer olma özelliğine de sahiptir. ${ }^{30}$ Bu kurumlar Abbasi halifesi Me'mûn zamanında en parlak çağını yaşamıştır. Onun döneminde Konstantin, Efes, Kıbrıs ve Bergama gibi şehirlerden felsefe ve mantık kitapları getirilmiştir. Halife de burada yürütülen ilmî çalışmalara büyük bir değer atfederek diğer dillerden Arapça'ya yapılan tercüme faaliyetlerini teşvik etmiştir. Bu hususta Me'mûn'un mütercimlere bahşiş olarak tercüme edilen eserlerin ağırlığınca altın verdiği rivâyet edilmektedir. ${ }^{31}$ Öte yandan i'tizâlî görüşlere meyliyle bilinen ve Mu'tezile'yi devletin resmî mezhebi ilan eden Me'mûn, bahsedilen eserlerin Arapça'ya çevirilmesini ve elde edilen bilgilerin Mu'tezilî fikirleri desteklemek üzere kullanılmasını emretmiştir. ${ }^{32}$

Mu'tezile mensupları da bu merkezlerde aktif rol alarak başta felsefe olmak üzere diğer dillerde yazılan eserleri Arap diline tercüme etmişler ve bu kitaplardan öğrendikleri usûl ve metotları ortaya koydukları dinî söylemlerde kullanmışlardır. ${ }^{33}$ Onların beytülhikmede özellikle felsefî eserlerdeki kavram ve 1stılahların Arapça'ya aktarımında önemli bir rol üstlendikleri görülmektedir. Bu konuda Câhız (ö. 255/869) Halîl b. Ahmed'in (ö. 175/791) "tavîl”, "basît" ve

${ }^{29}$ Şehristânî, el-Milel ve'n-nihal, s. 38; Marulcu, Kelâm-Belâgat İlişkisi, s. 52.

30 Hidır Ahmed Atâullah, Beytü'l-hikmeti fì 'asri'l-'Abbâsiyyîn, Dâru'l-Fikri'l-Arabî, Kahire tsz., s. 202; Mahmut Kaya, "Beytülhikme", TDV İslâm Ansiklopedisi, İstanbul 1992, c. VI, s. $88-90$.

${ }^{31}$ Atâullah, Beytü'l-hikme, s. 203, 209; Mustafa Demirci, “Antik Bilim ve Düşünce Mirasının İslâm Dünyasına Tercümesinde Abbasilerin Kurduğu Beytü'l-Hikme'nin Rolü’, Muhafazakâr Düşünce Dergisi, Y11: 2015, sy. 44, s. 109

32 Atâullah, Beytü'l-hikme, s. 203.

33 Gazi Erdem, "İslâm Kültür Tarihinin İlk İlimler Akademisi: Beytü'l-Hikme”, Dini Araştırmalar Dergisi, y1l: 2013, c. XVI, sy. 42, s. 65 
"kâmil" gibi aruz ilmindeki "bahir"34 adlarını; diğer nahiv âlimlerinin de "hal" ve “zarf” gibi nahiv ilmine dair birtakım kavramları ilk kez ortaya koydukları gibi Mu'tezile'nin de Araplar tarafindan daha önce kavramsal olarak bilinmeyen “cevher", "araz" ve "hüviyet" gibi istılahları icat ettiklerini söylemektedir. ${ }^{35}$ Buna göre Mu'tezile mensuplarının bir yandan Beytülhikmedeki Arapça’ya tercüme faaliyetlerinde aktif rol oynadıkları, diğer yandan da bu kurumu i'tizâlî görüşlerini yaymak için kullandıkları söylenilebilir. Nitekim özellikle halife Mu'tasım-Billâh döneminden sonra tercüme faaliyetlerinin yürütüldüğü beytülhikmenin, Mu'tezile'nin siyasî propagandaları için kullanılan bir merkeze dönüştüğü ifade edilmektedir. ${ }^{36}$

\section{Mu'tezile’nin Kur’ân Yorumunda Kullandı̆̆ı Dilsel Argümanlar}

Arap dili Mu'tezile için Kur’ân'ın tefsir edilmesinde önemli bir fonksiyon üstlenmekte olup âyetlerin tevilini yapacak kimsenin sadece Arapça konuşma ve yazma edimlerine sahip olması yeterli değildir. Müfessirin, Arap dilinin gramerini inceleyen nahiv ilminin ${ }^{37}$ yanı sıra belâgat alanında da müktesebat sahibi olması beklenmektedir. ${ }^{38}$ Mu'tezile'ye göre bir müfessir dil sahasındaki birikim ve tecrübesini -diğer dinî ilimlerde de olduğu gibi- mezhebin beş temel esasının özeti olarak kabul edilen tevhid ve adalet prensiplerine hizmet edecek şekilde kullanması gerekmektedir. ${ }^{39}$ Bundan hareketle mezhep mensuplarının yaptıkları tevillerde Arap dilinin, usûl-i hamseye hizmet ettiği ölçüde önem taşıdığg söylenilebilir. Şu husus belirtilmelidir ki Mu'tezile için Arap dili, i'tizâlî düşüncenin oluşumunda değil; aslında daha önceden benimsenmiş ideolojinin dile getirilmesinde devreye giren bir mekanizmadır. ${ }^{40}$ Burada mezhep mensuplarının i'tizâlî fikirlerini ifade ederken başvurdukları dilsel argümanlar; gramatik tahliller, belâgî yorumlar ve kıraat farklılıklarına dayanan dilsel izahlar başlıkları altında incelenecektir.

\subsection{Gramatik Tahliller}

\footnotetext{
34 Bahir, şiirin yazımı esnasında şairin gözettiği belli tef'ilelerden oluşan özel bir vezne verilen isimdir. Aruz ilminde toplam onaltı bahir bulunmakta olup; bunların onbeşini Halîl b. Ahmed ortaya koymuştur. Bkz. Hüseyin Tural, Arap Edebiyatında Aruz, Ensar Yayınları, İstanbul 2011, s. 55.

${ }^{35}$ Câhiz, el-Beyân ve't-Tebyîn, c. I, s. 139-140.

36 Necati Avc1, "İslâm Dünyasında Kütüphaneciliğin Doğuşu ve İlk Örnekleri (Beytü'lHikme'den Dâru'l-Hikme'ye)", Eskişehir Osmangazi Üniversitesi Sosyal Bilimler Dergisi, 2000 , s. 10 .

${ }^{37}$ Kâdî Abdülcebbâr, Şerhu'l-usûli'l-hamse, s. 606.

${ }^{38} \mathrm{Mu}$ 'tezile'nin belâgat ilmine dair yaptığ ${ }_{1}$ atıflar, bu alanın teșekkül sürecine bağlı olarak hicrî 6. asırda Zemahşerî ile birlikte daha belirgin bir hâl aldığı gözlemlenmektedir. Bkz. Zemahşerî, el-Keş̧̧âf, c. I, s. 7.

${ }^{39}$ Bkz. Kâdî Abdülcebbâr, Şerhu'l-usûli'l-hamse, s. 606.

${ }^{40} \mathrm{Bu}$ hususta detaylı bilgi için bkz. Galip Türcan, Kelam İlminde Bilgi Kaynăğ Olarak Kitâb, İz Yayınc1lık, İstanbul 2015, s. 211-222.
} 
Mu'tezile’nin, mezhebî fikirlerini ortaya koymak üzere yaptığı gramatik yorumlar nahiv ilminin sınırları içerisinde ele alınabilir. Sözlükte "yönelmek, kastetmek ve izini sürmek" gibi manalarda kullanılan nahiv, bir disiplin olarak "i'râb ve binâ açısından kelimenin cümledeki konumunun tespit edilmesini sağlayan kurallar" şeklinde tarif edilmektedir. ${ }^{41}$ Temelleri Ebu'l-Esved ed-Düelî (ö. 69/688) tarafından atılan bu ilmin ${ }^{42}$ tarihî süreç içerisinde sistematize edilerek kayıt altına alınması, dinî ilimlerin dilsel içerikler kazanması üzerinde etkili olmuştur. Bu hususta ilk dönem kelâm kitaplarında âyetlerin izahı için gramer kurallarına yoğun bir şekilde yer verilmediği; sonraki dönemlerde ise bu hususun giderek yaygınlık kazandığı ifade edilmektedir. ${ }^{43}$ Nitekim nahiv ilmi, ortaya çıkışında da tanık olunduğu üzere âyetlerin murad-1 ilâhiye uygun şekilde anlaşılması açısından özel bir konumda bulunmaktadır. ${ }^{44}$ Öte yandan bu ilmin kelâm disiplininde yorumun temel dinamiklerinden birini teşkil ettiği de belirtilmelidir. ${ }^{45}$ Mezhebî düşüncelerini dil ile temellendirme amacı taşıyan Mu'tezile de Arap dilinin gramer boyutuyla ilgilenerek bu sahada çeşitli çalışmalar yürütmüştür. Nitekim İbnü’l-Mukadder (ö. 442/1050) tarafından Mu'tezilî dilcilerin isimlerinden ve nahiv ilmine sundukları katkılardan bahseden bir kitap yazıldığ 1 söylenmektedir. ${ }^{46}$ Söz konusu eser her ne kadar günümüze ulaşmamış olsa da Zeydî kimliği ile meşhur İbnü’l-Murtezâ'nın (ö.

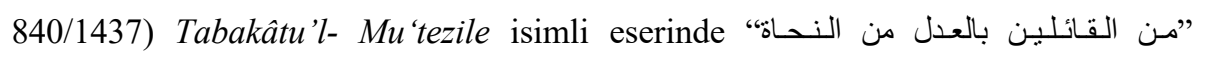
"Nahivcilerden adalet öğretisini (usûl-i hamseyi) savunanlar" başlığı altında nahiv ilmiyle uğraşan mezhep müntesiplerinden bahsettiğine tanık olunmaktadır. ${ }^{47}$

41 Zebîdî, Ebu'l-Feyz Muhammed el-Murtazâ, Tâcu'l-'arûs min cevâhiri'l-kâmûs, thk. Mahmud Muhammed et-Tanâhî, et-Türâsü'l-Arabî, Kuveyt 1993, c. XL, s. 45; Cevherî, Ebû Nasr İsmâil b. Hammâd, es-Sihâh -Tâcu'l-luğa ve sihâhu'l-'Arabiyye-, (nşr. Muhammed Tâmir-Enes Muhammed eş-Şâmî-Zekeriyyâ Câbir Ahmed), Dâru'l-hadîs, Kahire 2009, s. 1120 .

42 İbnu'l-Enbâri, Kemaluddîn Abdurrahmân, Nuzhetu'l-elibbâ fì tabakâti'l-udebâ, (nşr. İbrahim Samurâî), Mektebetü'l-Menâr, Ürdün, 1985, s. 18; Şevki Dayf, el-Medârisü'nnahviyye, Dâru'l-Meârif, Kahire 2008, s. 15.

43 Türcan, Kelam İlminde Bilgi Kaynăğ Olarak Kitâb, s. 211.

44 İbn Haldûn, Ebû Zeyd Veliyyüddîn Abdurrahmân, Mukaddimetü İbn Haldûn, thk. Abdullah Muhammed ed-Dervîş, Dâru'l-Belhî, Dımaşk 2004, c. II, s. 367; Turan Bahşi, "Arapçada "Lahn”ın Dil Çalışmalarına Etkisi”, Turkish Academic Research Review (TARR), yı1:5 sayı: 4, s. 600 .

${ }^{45}$ Güman, Nahiv ve Fıkıh Usûlü Illişkisi, s. 32.

46 Talâl Yahyâ İbrâhîm-Sâmir Abdülcebbâr Nâsıf, "en-Nuhâtü'l-Mu'tezile", Âdâbu'rRâfideyn, sy. 45, 2007, s. 2.

47 İbnü'l-Murtazâ, Mehdî Lidînillâh Ahmed b. Yahyâ, Tabakâtu'l-Mu 'tezile, Beyrut 1971, s. 131. İbnü'l-Murtezâ sözü edilen bölümde Kutrub (ö. 210/825), Ahfeş el-Evsat (ö. 215/830) ve İbn Cinnî (ö. 392/1002) gibi Mu'tezilî nahivcilerin adlarını sıralamaktadır. Öte yandan o bu listede mezhebî taassubunun da etkisiyle Ebu'l-Esved ed-Düelî (ö. 69/688), Îsâ b. Ömer (ö. 149/766) ve Halîl b. Ahmed (ö. 175/791) gibi kaynaklarda i'tizâlî görüşleri benimsediğine dair herhangi bir bilgi bulunmayan dil âlimlerinin isimlerine de yer vermektedir. 
Mezhep mensuplarının i'tizâlî söylemlerini Kur’ân'a dayandırmak üzere kullandığı gramatik izahların "i‘râb” ağırıklı olduğu görülmektedir. " “أعْرَبَ" fiilinin masdarı olan i'râb kelimesi sözlükte, "bir şeyin hakikatini ortaya çıkarmak ve bir şeyi açıklamak" gibi manaları ifade etmektedir. Bir terim olarak i'râb "kelimenin cümle içinde fâil, nâib-i fâil ve mübtedâ gibi sahip olduğu konumlara işaret eden bilgiler” şeklinde tarif edilebilir. ${ }^{48}$ Mu'tezile'nin i'râbı bir tevil enstrümanı olarak benimsemesinin arkasında i'râb ve anlam arasındaki ilişkiyi ${ }^{49}$ mezhebî saiklerle kullanma arzusu bulunmaktadır. Nitekim lafzın i'râbında yapılan küçük değişimler ifade edilmek istenilen anlamda kimi zaman büyük farklılıkları beraberinde getirmektedir. $\mathrm{Bu}$ nedenle $\mathrm{Mu}$ ‘tezile'nin itikadî hüküm bildiren âyetlerde i'râba bakış açısının, anlamı önceleyen bir tavır barındırdı̆̆ı söylenilebilir. Diğer bir ifadeyle onlar, âyetlerin anlamlarını mezhebî fikirlerine göre sabitleyip i'râb çözümlemelerini bu doğrultuda yapmışlardır. Bahsedilen durum kimi zaman farklı i'râb değerlendirmeleri sebebiyle âyetin bağlamından uzaklaşmalarına da sebep olmuştur. Şöyle ki âyetlerin gramatik çözümlemelerinin yapıldığg eserlerde onlara özgü bahsedilen i'râb çözümlemeleri kimi zaman " هَذَا إعْرَابُ المُعنَزَلَة "Bu, Mu'tezile'nin i'râbıdır." şeklinde betimlenmiştir. ${ }^{50}$

Örneğin Mu'tezile adalet prensibi uyarınca Allah'ın bütün fiillerinin iyi ve güzel (hasen) olduğunu dolayısıyla O'na kötü ve çirkin (kabîh) olarak gördükleri fiillerin isnat edilemeyeceğini savunmaktadır. Diğer bir deyişle onlar Allah'ın, hasen kabul ettikleri fiiller işlediğini, kabîh gördükleri eylemlerin ise insandan kaynaklandığını düşünmektedirler. ${ }^{51} \mathrm{Bu}$ düşünceden hareketle mezhep mensuplarının, insanın eylemlerinin (ef'âl-i ibâd) yaratıcısını insan olarak

\footnotetext{
48 İbn Manzûr, Ebu'l-Fazl Cemâlüddîn Muhammed b. Mükerrem, Lisânu'l-'Arab, Dâru Sâdır, Beyrut tsz., c. I, s. 588-593; Cevherî, es-Sihâh, s. 748-749; Cürcânî, Ebu'l-Hasen esSeyyid eş-Şerîf, Kitâbu't-ta 'rifât, thk. Âdil Enver Hızır, Dâru'l-Ma'rife, Beyrut 2007, s. 34; Emîl Bedî Yakûb, Mevsûatu 'ulûmi'l-luğati'l-'Arabiyye, Dâru'l-Kütübi'l-İlmiyye, Beyrut 2006, c. II, s. 296. Kur'ân'ın anlaşılmasında i'râbın önemine dikkat çeken Zerkeşî (ö. 794/1392), Kur'ân'ı araştıran ve onun inceliklerini öğrenmek isteyen bir kişinin âyetlerde yer alan ifadelerin mübtedâ-haber, fâil-mef' ûl gibi i'râb konumlarına dikkat etmesi gerektiğini belirtmektedir. Bkz. Zerkeșî, Ebû Abdillâh Bedrüddîn Muhammed, el-Burhân fî 'ulûmi'lKur'ân, thk. Muhammed Ebu'l-Fazl İbrâhim, Mektebetü Dâru’t-Turâs, Kahire tsz, c. I, s. 302. 49 Bahsedilen ilişkiye Mu'tezile'den İbn Cinnî (ö. 392/1002) el-Hasâis adlı kitabında

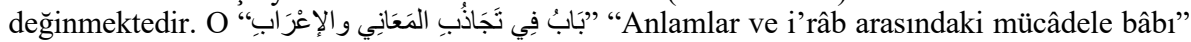
başlığı altında i'râb ve anlamın çatışması durumunda esas alınması gereken tarafın anlam olduğunu dolayısıyla i'râb çözümlemelerinin anlam odaklı yapılması gerektiğini ifade etmektedir. Bkz. İbn Cinnî, el-Hasâis, c. III, s. 255.

${ }^{50}$ Semîn el-Halebî, Ebu'l-Abbâs Şihâbüddîn Ahmed, ed-Dürrü'l-mesûn fì 'ulûmi'l-Kitâbi'lmeknûn, thk. Ahmed Muhammed el-Harrât, Dâru'l-Kalem, Dımaşk tsz., c. X, s. 255; Ebû Hayyân, Muhammed b. Yûsuf el-Endelüsî, el-Bahru'l-muhît, Dâru'l-Kütübi'l-İlmiyye, Beyrut, 1993, c. VIII, s. 226; İbrâhîm-Nâsıf, "en-Nuhâtü'l-Mu'tezile”, s. 2.

${ }^{51}$ Kâdî Abdülcebbâr, Şerhu'l-usûli l-hamse, s. 133-134.
}

Turkish Academic Research Review - Türk Akademik Araştırmalar Dergisi 
belirledikleri ve bu hususta söz birliği içerisinde oldukları ifade edilmektedir. ${ }^{52}$

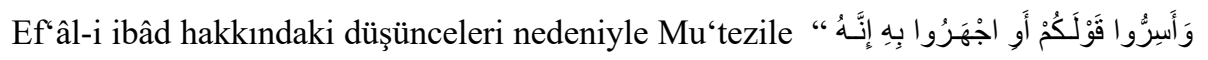

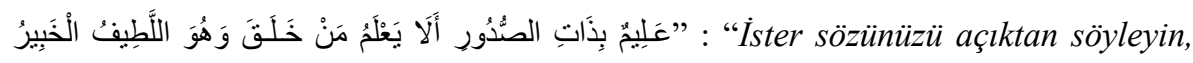
ister gizleyin; O, içinizde olanı bilir. Yaratan (Allah) bilmez mi hiç?! O, latîftir,

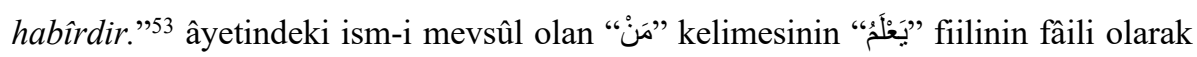
merfû olduğunu kabul etmekten uzak durmaktadır. Zira bahsedilen i'râb çözümlemesine göre anlam, meâli verilen şekilde ortaya çıkmakta yani hem gizli hem de aşikâr bütün sözlerin dolayısıyla da insanların fiillerinin yaratıcısının Allah olduğunu kanıtlamaktadır. ${ }^{54}$ Ancak mezhep mensuplarından Ca'fer b. Harb (ö. 236/850) ve Ebû Bekr el-Esam (ö. 200/816) âyeti mezhebî fikirleriyle uyumlu hale

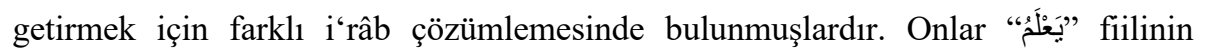
fâilinin, fiil içindeki Allah'a râci müstetir "هو" olduğunu ve " "مَ" kelimesinin ise

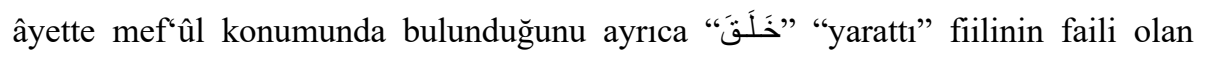
müstetir "هو" zamirinin insana râci olduğunu ileri sürmek suretiyle âyetin "Allah, kulunun yarattığını bilmez mi hiç!” şeklinde bir anlam taşıdığını iddia etmişlerdir. ${ }^{55}$

Mu'tezile'nin ef'âl-i ibâd konusunda itikadî düşüncelerine uygun i'râb

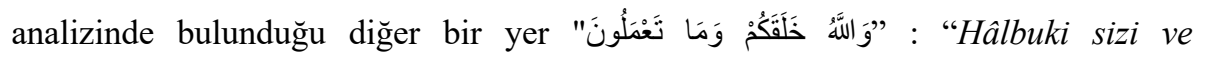
yaptıklarınızı (eylemlerinizi/putları) Allah yarattı." bazı "mâ/Lَ" kalıplarının ism-i mevsûl ya da masdariyye olma durumlarını bir anlam zenginliği olarak telakki eden Zemahşerî́ ${ }^{57}$ bu âyetin tefsirinde söz konusu tavrından vazgeçmek durumunda kalmaktadır. Ona göre âyetteki "mâ" kelimesine "ellezî/الذي" yani ism-i mevsûl anlamı verilmelidir. Bu izahın ardından müellif “"Mâ/ıّo' kelimesine ism-i mevsûl anlamı verdin de, neden Cebriyye'nin dile getirdiği masdariyye olmasını inkâr ettin ve âyeti 'Allah sizi ve eylemlerini yarattı.' gibi anlamadın?" 58 şeklinde bir soruya yanıt aramaktadır. Burada Zemahşerî, mezhebinin "halku'l-ef'âl” konusundaki söylemleriyle çelişmemek için "mâ"nın masdariyye anlamına hamledilmesine karşı çıkmakta ve ism-i mevsûl manasında kullanıldığını ispat etmeye çalışmaktadır. Böylece o, âyetten insanın kendi fiillerinin yaratıcısı

\footnotetext{
52 Sehristânî, el-Milel ve'n-nihal, s. 39.

53 Mülk 67/13-14.

${ }^{54}$ Nesefî, Ebu'l-Berekât Hâfizüddîn Abdullah, Medâriku't-tenzîl ve hakâlku't-te'vîl, Dâru İbn Kesîr, Beyrut 2005, c. III, s. 514.

${ }_{55}$ Mâtürîdî, Ebû Mansûr Muhammed, Te'vîlatü'l-Kur'ân, Mizan Yayınları, İstanbul 2010, c. XV, s. 301; Nesefî, Medâriku't-tenzîl, c. III, s. 514.

${ }^{56}$ Saffât $37 / 96$.

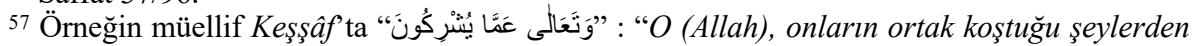
münezzeh ve yücedir" 57 (Yûnus 10/18) âyetinde bulunan "mâ" kelimesinin ism-i mevsûl ve masdariyye anlamları taşıyabileceği ihtimali üzerinde durmaktadır. (Zemahşerî, el-Keşşâf, c. II, s. 325.) Benzer açıklamalar için bkz. Zemahşerî, el-Keşşâf, c. II, s. 415, 495-496.

58 Zemahşerî, el-Keşşâf, c. IV, s. 49.
} 
olduğu fikrine aykırı bir mana anlaşılmasının önüne geçmek istemektedir. Ardından müellif "mâ"yı masdariyye olarak yorumlayanları Arap dilini bilmemekle ve mezhebi taassuba sahip olmakla suçlamaktadır. ${ }^{59}$ Şunu belirtmek gerekir ki Zemahşerî söz konusu "mâ"yı masdariyye olarak tevil edenleri mezhebî önyargılara sahip olmakla eleştirirken kendisi de bu harfi i'tizâlî fikirlerinin etkisiyle salt mevsûle olarak belirlemekle aynı türden bir tavır sergilemektedir. Çünkü söz konusu âyetteki "mâ/־َ"nın masdariyye olarak anlaşılması da Arap dili açısından makul bir yorum $^{60}$ olarak karşımıza çıkmaktadır. Ancak Zemahşerî bu anlam zenginliğini i‘tizâlî saiklerle görmezden gelmektedir.

Mezhep mensuplarının itikadî eğilimleri doğrultusunda i'râb

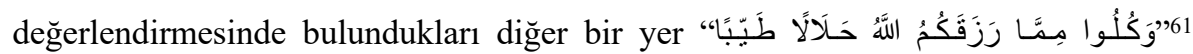
âyetidir. Mu'tezile rızık kavramına yüklediği anlama uygun bir şekilde bu âyeti i'râb etmiştir. ${ }^{62}$ Şöyle ki onlar rızkın sadece helal şeylerden ibaret olduğunu buna mukabil haram yollarla ele edilen şeylerin rızık olamayacağını iddia etmişlerdir. Bahsedilen fikir, haram yiyen ya da hayatı boyunca haramdan geçimini temin eden kişilere Allah'tan başkasının rızık vermesi gibi yanlış bir sonuca ulaştırması nedeniyle tenkit edilmiştir. ${ }^{63} \mathrm{Mu}$ 'tezile benimsediği rızk anlayışına uygun bir şekilde âyetteki “ “حَلَالَ طِطيَّ" ifadesini şöyle i'râb etmektedir: Onlara göre bahsedilen ifade, öncesinde geçen

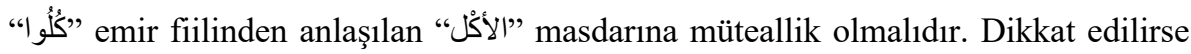
onların yaptıkları i'râb çözümlemesine göre helal ve temizlik vasıfları rızk olarak verilen şeyin bir nitelemesi olarak kabul edilmemekte ve âyete "Allah'ın size rızık olarak verdiği şeyleri helal ve temiz bir şekilde yiyin!" şeklinde bir mana yüklenmektedir. Bu anlam üzerinden Mu'tezile şu önermeyi kurmaktadır:

Allah, rızık olarak verdiklerinin yenilmesine izin vermiştir.

O'nun yenilmesine izin verdikleri, helal bir şekilde yenilenlerdir.

Bundan hareketle rızık olan her şey, helal bir şekilde yenilenlerdir. ${ }^{64}$

Görüldügü gibi Mu'tezile, âyeti ilk olarak mezhebî düşünceleri doğrultusunda i'râb etmekte, ardından da i'râb farklılı̆ğ ile ortaya çıkan anlamı mantık kuralları çerçevesinde itikadî fikirlerini destekleyecek şekilde

${ }^{59}$ Zemahşerî, el-Keşşâf, c. IV, s. 50.

${ }^{60}$ Nesefî, Medâriku't-tenzîl, c. III, s. 130; İbnü'l-Müneyyir, Ebu'l-Abbâs Nâsırüddîn Ahmed, el-İnsâf fì mâ tedammenehü'l-Keş̧̧âf (Keş̧âff zeylinde), Dâru'l-Kütübi'l-İlmiyye, Beyrut 2015, c. IV, s. 49.

${ }^{61}$ Mâide 5/88.

${ }^{62}$ Râzî, Ebû Abdillâh (Ebu'l-Fazl) Fahrüddîn, Mefâtîhu'l-ğayb: et-Tefsîru'l-kebîr, Dâru Fikr, Lübnan 1981, c. XII, s. 77.

${ }^{63}$ Teftâzânî, Sa'düddîn Mes'ûd b. Fahriddîn, Şerhu'l- 'Akâidi'n-Nesefiyye, thk. Ahmet Hicâzî es-Sekkâ, Mektebetü'l-Külliyyâti'l-Ezheriyye, Kahire 1987, s. 64-65; Şerafeddin Gölcük, "Rızık", TDV İslâm Ansiklopedisi, İstanbul 2008, c. XXXV, s. 73.

${ }^{64}$ Râzî, Mefâtîhu'l-ğayb, c. XII, s. 77.

Turkish Academic Research Review - Türk Akademik Araştırmalar Dergisi 


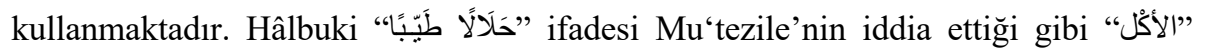
"yeme" eylemine değil; bunun yerine "المأكول" yani "yenilen şeye" de müteallik olması dilsel açıdan mümkündür. Böylece söz konusu âyetin meali; "Allah'ın size verdiği rızıktan helal ve temiz olanı yiyin." şeklinde ortaya çıkmaktadır. Dolayısıyla âyet, rızkın bazı durumlarda haram olduğunu ve Allah Teâlâ'nın yenilecek şeyleri helal ve hoş olan rızka tahsis ettiğini ortaya koymaktadır. Buna mukabil Mu'tezile'nin ileri sürdüğü i'râb çözümlemesi ise âyetteki tahsîs ve takyîdi işlevsiz hale getirmektedir. ${ }^{65}$

Mu'tezile'nin mezhebî aidiyetleri bağlamında yaptığı gramatik izahlar arasında kimi zaman kelimelere yüklenilen farklı anlamlarla da karşılaşılmaktadır. Örneğin mezhep mensupları Allah'ın dünya hayatında imân ve itaat eden kullarına mükâfat vereceğini (va'd), âsilere de ceza tehdidinde (va'îd) bulunduğunu dolayısıyla itaatkâr mü’minlere mükâfat, âsilere de ceza verilmesinin Allah için zorunlu (vâcip) olduğunu ileri sürmektedirler. ${ }^{66} \mathrm{Bu}$ anlayış ekseninde $\mathrm{Mu}$ 'tezilî

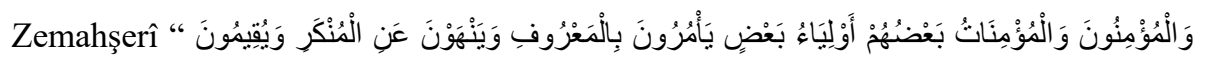

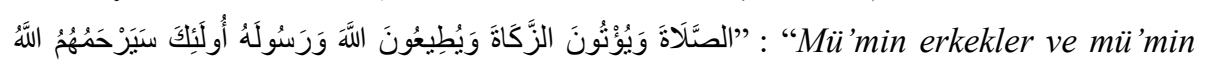
kadinlar birbirlerinin velîleridir. Onlar ma'rûfu emredip münkeri yasaklarlar, namazı dosdoğru kilar, zekâtı verirler, Allah ve Rasulüne itaat ederler. Allah işte bunlara rahmet eder. "67 âyetini tefsir ederken tenfis harflerinden olan "sîn/السين" harfinin 68 "kat'iyyet/kesinlik" anlamı taşıdığını ileri sürmektedir. ${ }^{69}$

Zemahşerî̀nin bu harfe "kat'iyyet/kesinlik" anlamı vermesi Ebû Hayyân'ın (ö. 745/1344) da belirttiği üzere “i'tizâlî bir kaygı"dan kaynaklanmaktadır. Şöyle ki Zemahşer̂̀’nin yaptığı dilsel izahının nirengi noktası, gerek günahkâr bir kimsenin cezalandırılması gerekse itaat eden bir mü’minin mükâfatlandırılması gibi konularda Allah'a vücûbiyet isnat eden i'tizâlî mefkûrenin temellendirilmesidir. Ebû Hayyân bu konuda Zemahşerî’nin dilsel bir hataya düştüğünü çünkü "sîn/السين" harfinin, muzâri fiilin anlamını gelecek zamana tahsis

${ }^{65}$ Râzî, Mefâtîhu'l-ğayb, c. XII, s. 77.

${ }^{66}$ Kâdî Abdülcebbâr, Şerhu'l-usûli'l-hamse, s. 135-136.

67 Tevbe $9 / 71$.

68 Muzâri fiil, yalın bir şekilde yani "sîn/للِيِّ" harfi kullanılmadan, hâl (şimdiki zaman) ya da müstakbel (gelecek zaman ve geniş zaman) anlamı ifade etmektedir. Buna karşın söz konusu harf eklendiği muzari fiilin zaman anlamı sınırlandırarak gelecek zamana tahsis etmektedir.

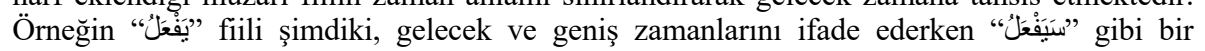
kullanım, fiilin bildirdiği oluşun (hades) gelecek zamanda ortaya çıkacağını göstermektedir. Detaylı bilgi için bkz. Radî el-Esterâbâdî, Muhammed b. el-Hasen, Şerhu'r-Radî 'ale'lKâfiye, Câmiatu Karyunus, Bingazi 1996, c. IV, s. 6; İbnü's-Serrâc, Ebû Bekr Muhammed, el-Usûl fi'n-nahv, thk. Abdulhüseyn el-Fetlî, Müessesetü'r-Risâle, Beyrut 1985, c. I, s. 39.

${ }^{69}$ Zemahşerî, el-Keşş̧âf, c. II, s. 280. 
eden bir kelimeden ibaret olduğunu belirtmektedir. ${ }^{70}$ Ebû Hayyân'ın yanı sıra İbn Hişâm (ö. 761/1360) da Zemahşerî’nin va‘d ve va‘îd bildiren fiillerin başına gelen "sîn/السين" harfine ilişkin izahlarının gramatik temellerden yoksun olduğunu söyleyerek bu harfe kesinlik anlamı veren bir nahiv âlimi bulunmadığına dikkat çekmektedir. $^{71}$

Mezhep mensuplarının itikadî fikirleri doğrultusunda kelimelere yükledikleri farklı anlama diğer bir örnek olarak "Len/نَّ" harfi" verilebilir. Bu harf başına eklendiği muzâri fiilin i'râbını etkilemekte ve fiilin anlamını olumsuza dönüştürerek zamanını geleceğe tahsis etmektedir. ${ }^{73}$ Ayrıca gramer kitaplarında "len/ل harfinin, olumsuza dönüştürdüğü anlamı tekit ettiği de belirtilmektedir. ${ }^{74}$ Mu'tezile'nin ideolojik gayelerle bu harfin anlamına ilişkin yaptığı müdahele " وَلَمَّا

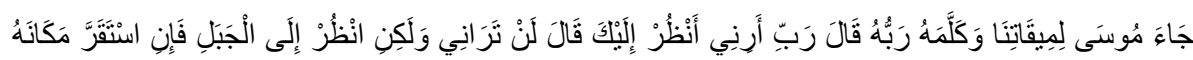

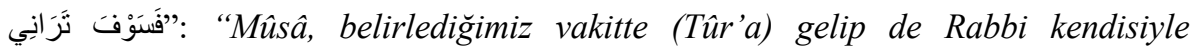
konuştuğunda o, 'Ya Rabbi! Bana kendini göster de sana bakayım.' dedi. Rabbi, 'Sen beni göremezsin. Ama şu dă̆a bak! Şayet o, yerinde durabilirse; o zaman sen de Beni görürsün' buyurdu." âyetinde açık bir şekilde görülmektedir. Nitekim Mu'tezile'den Kâdî Abdülcebbâr Şerhu'l-usûli'l-hamse adlı eserinde mezhebinin

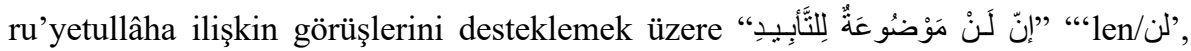
(olumsuzlanan ifadenin) ebedîlik durumunu göstermek üzere vaz" edilmiştir." 75 demektedir. Böylece o "len/لَنْ" ile ortaya çıkan olumsuz anlamın ilâ nihâye âhirette de devam edeceğini ileri sürmektedir.

Kâdî Abdülcebbâr'ın "len/ََنَ" harfinin vaz'ına ilişkin ileri sürdüğü fikir, birtakım tartışmaları da beraberinde getirmiştir. Ondan yaklaşık yarım asır sonra yaşayan ve müfessir kimliğinin yanı sıra Arap dili alanındaki çalışmalarıyla da tanınan Vâhidî (ö. 468/1076) söz konusu harfe ebedîlik anlamının verilmesine karşı çıkmıştır. O, dilcilerin referans gösterilerek "len/"نَ" kelimesine ebedîlik anlamı yüklenmesinin, onlara yapılmış bir iftiradan ibaret olduğunu belirtmektedir. Ayrıca

\footnotetext{
${ }^{70}$ Ebû Hayyân, el-Bahru'l-muhît, c. IV, s. 34.

71 İbn Hişâm, Ebû Muhammed Cemâlüddîn en-Nahvî, Muğni'l-lebîb an kütübi'l-e 'ârî̉b, thk. Abdullatîf Muhammed el-Hatîb, es-Silseletü’t-Türâsiyye, yy. tsz., c. II, s. 345-346.

72 "Len/ لَنْ "in, türetilmesine dair nahiv âlimleri arasındaki ihtilaf için bkz. Suyûtî, Ebu'l-Fazl Celâlüddîn, Hem 'ul-hevâmi' fì şerhi Cem 'il-cevâmi', thk. Ahmed Şemsuddîn, Dâru'lKütübi'l-İlmiyye, Beyrut 1998, c. II, s. 286.

${ }^{73}$ İbn Hişâm, Muğni'l-lebîb, c. III, s. 501; Ebu'l-Bekâ, Eyyûb b. Mûsâ el-Hüseynî el-Kefevî, el-Külliyyât - Mu'cemun fìl-mustalahâti ve'l-furûki'l-luğaviyye, thk. Adnan Derviș Muhammed el-Misrî, Müessesetü'r-Risâle, Beyrut 1998, s. 791.

${ }^{74}$ Suyûtî, Hem 'ul-hevâmi, c. II, s. 286; İbn Hișâm, Muğni 'l-lebîb, c. III, s. 501

${ }^{75}$ Kâdî Abdülcebbâr, Şerhu 'l-usûli'l-hamse, s. 264
} 
Vâhidî muteber kabul edilen kitaplarda böyle bir görüş ortaya atılmadığını söylemektedir. ${ }^{76}$

Buna karşın sonraki tarihsel süreçte $\mathrm{Mu}$ ‘tezile saflarında Kâdî Abdülcebbâr gibi Zemahşerî’nin de "len/نَ' kelimesine ebedîlik anlamı verdiği görülmektedir. Zemahşerî zikredilen âyeti tefsir ederken ru'yetullâhın Allah'ın sıfatlarına aykırı olduğunu iddia etmektedir. Ona göre Vâsıl b. Atâ (ö. 131/748), Amr b. Ubeyd (ö. 144/761), Ebû İshâk en-Nazzâm (ö. 231/845), Ebu'l-Huzeyl elAllâf (ö. 131/748), Ebû Ali el-Cübbâî (ö. 303/916) ve Ebû Hâşim el-Cübbâî (ö. 321/933) gibi Mu‘tezilîlerden daha üstün bir şekilde Allah’1 tanıyan Hz. Mûsâ

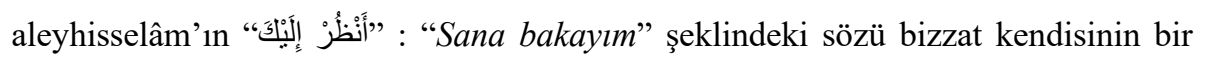
isteği olmayıp; bu ifade İsrâiloğullarının dile getirdiği bir talebin hikâye edilmesi şeklinde anlaşılmalıdır. ${ }^{77}$ Ardından Zemahşerî 'len' kelimesinin bir işin gerçekleşmesinin muhâl olduğunu nitelemek üzere kullanıldığını göstermektedir. O,

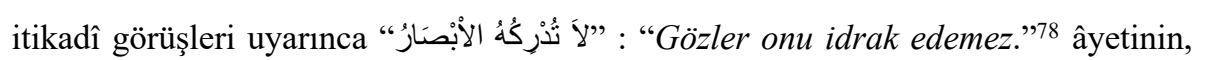

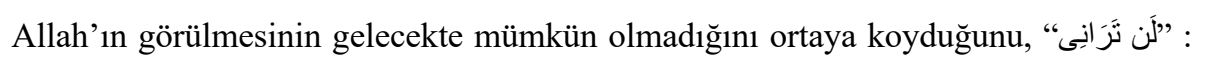
“Beni asla göremezsin" âyetinde ise bu durumun vurgulu bir şekilde ifade edildiğini iddia etmektedir. ${ }^{79}$

Zemahşerî’nin "len/لن" harfinin anlamınına yaptığı müdahele, dilci kimliği ile meşhur âlimler tarafından eleştirilmiş ve bu tercihin i'tizâlî aidiyetlere dayandığı ifade edilmiştir. Sözgelimi İbn Mâlik (ö. 672/1274) nahiv ilminde kaleme aldığı el-Kâfiyetü'ş-şâfiye isimli manzumesinde ${ }^{80}$ şu beyte yer vermektedir:

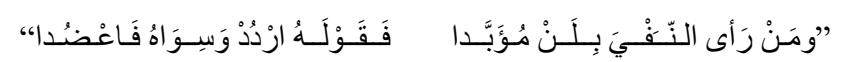

“Her kim hükmederse; len/نَile gerçekleşen nefyin, ebedî olduğuna

Reddet bu görüşü, sen sarll gayrına!",81

\footnotetext{
76 Vâhidî’ye göre bu iddianın mesnetsiz olduğunu ortaya koyan delillerden biri de Yahudîlerin

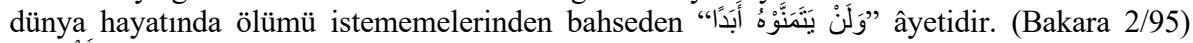
"len/نَّ" harfinin ebedîlik anlamına hamledilmesine mebni âyetten Yahudîlerin gerek dünyada gerekse âhirette hiçbir şekilde ölümü temenni etmeyeceklerinin anlaşılması gerekmektedir. Oysaki onlar, kıyâmet gününde ölümü temenni edeceklerdir. Râzî, Mefâtîhu'l-ğgayb, c. XIV, s. 237-244.

77 Zemahşerî, el-Keşşâf, c. II, s. 148-149.

${ }^{78}$ En'âm 6/103

${ }^{79}$ Zemahşerî, el-Keşşâf, c. II, s. 148-149.

80 el-Kâfiyetü’ş-şâfiye Arap dilinin gramere ilişkin konularının ele alındığı 2557 beyitlik bir manzumedir. İbn Mâlik bu eseri dil öğretiminde pratik bir fayda sağlama amaciyla daha sonra özetleyerek el-Elfiyye isimli manzumesini hazırlamıştır. Daha geniş bilgi için bkz.: Turan Bahşi, İbn Mâlik ve Nahiv İlmi Açısından el-Elfiyye Adlı Eseri, (Yayınlanmamış Yüksek Lisans Tezi), Akdeniz Üniversitesi Sosyal Bilimler Enstitüsü, Antalya 2012, s. 31-32.

81 İbn Mâlik, Şerhu'l-Kâfiye, thk. Abdulmun'im Ahmed Herîrî, Dâru'l-Menâmûn li't-Türâs, yy. 1982 c. III, s. 1531; İbnu Ebi'l-İz, Ebu'l-Hasen Sadruddîn, Şerhu'l-'Akîdeti’t-Tahâviyye,
} 
İbn Mâlik bu satırlarda ebedîlik anlamı veren kişinin kimliğini açıkça zikretmese de o, el-Kâfiyetü'ş-şâfiye'ye yaptığı şerhinde bu kişinin Zemahşerî olduğunu söylemektedir. Ona göre Zemahşerî’nin "len/لَّ" harfini ebedîlik anlamına hamletmesi, Allah'ın görülemeyeceği şeklindeki mezhebî düşüncesinden kaynaklanmaktadır. Bunun yanı sıra İbn Mâlik, ru'yetullâh'ı bildiren âyet ve sahih hadislerin varlığı nedeniyle Zemahşerî’nin benimsediği düşüncenin doğru olmadığına dikkat çekmektedir. Zemahşerı̂’ye yönelttiği tenkitlerin ardından o, Allah Teâlâ'dan ru'yeti inkâr etmekten kendisini korumasını ve ru'yetle şereflenen kullar zümresine dâhil olmayı istemektedir. ${ }^{82}$ İbn Mâlik'in Zemahşerî özelinde Mu'tezile’ye yönelttiğgi eleştiriler birçok dilci tarafindan benzer şekillerde tekrarlanmaktadir. ${ }^{83}$

Mu'tezile taraftarları "len" harfinde de görüldügü̈ üzere kelimenin anlamına ilişkin açıklamalarında tıpkı i'râb çözümlemelerinde yaptıkları gibi mezhebî fikirlerini öncelemişlerdir. Bundan hareketle özellikle i'tizâlî fikirlerine aykırı buldukları âyetlerin tevilinde, Mu'tezile'nin yaptığı gramatik tahlillerin, nastan hareketle düşünceyi kurma gibi bir gaye ile yapılmadığı bunun yerine ideolojik aidiyetlerin Kur'ân'a dayandırılması gibi mezhebî bir amacı gerçekleştirmek üzere bahsedilen dilsel çözümlemelere yer verildiği söylenilebilir. $\mathrm{Bu}$ durum örneklerde de görüldüğü üzere kimi zaman onların dilin tabiatında bulunmayan birtakım dilsel çıkarımlar yapmalarını ve bu tavrın eleştirilmesini de beraberinde getirmiştir. Söz konusu eleştirilerin dil ilimlerinin öğretimini hedefleyen temel eserlere taşınması ve satır aralarında bu türden tenkitlere yer verilmesi ise dikkat çekicidir. Bahsedilen eserlerde karşılaşılan Mu'tezile eleştirilerinin; dilin, kişiler ve gruplardan bağımsız bir kimliğe sahip olduğunu ve bünyesinde barındırdığı kurallara aykırı sayılabilecek eklentilere boyun eğmediğini ${ }^{84}$ ortaya koyma çabası olarak okunması mümkün gözükmektedir. Mezhep mensupları i‘tizâlî fikirlerini Kur'ân'a dayandırmak amacıyla sadece gramatik izahlarda bulunmamış ayrıca belirtilen amacı gerçekleştirmek üzere Arap dilindeki mecâz olgusunu kullanmışlardır. Onların mecâza dair söylemleri, belâgat içerikli yorumlar üzerinden incelenebilir.

\subsection{Belâgî Yorumlar}

thk. Abdullah b. Abdülmuhsin et-Türkî ve Şuayb el-Arnavût, Müessesetü’r-Risâle, yy. tsz., c. I, s. 214

82 Bkz. İbn Mâlik, Serhu'l-Kâfive, c. III, s. 1531.

83 Örneğin bkz. İbn Hişâm, Muğni'l-lebîb, c. III, s. 504-504; Ebu'l-Bekâ, el-Külliyyât, s. 791792.

${ }^{84}$ Hüseyin Küçükkalay, Kur'ân Dili Arapça, Denizkuşları Matbaası, Konya 1969, s. 13-14.

Turkish Academic Research Review - Türk Akademik Araştırmalar Dergisi 
Sözlükte, "varmak, hedefe ulaşmak ve son bulmak" gibi anlamlar ifade eden belâgat ${ }^{85}$ Arap diline dair ilimler içinde tekâmülünü en geç tamamlayan ilimdir. Nitekim ilk dönemlerde belâgatın "güzel ve etkili konuşma melekesi" 86 olarak tanımlandığı ve tarihsel süreç içerisinde bu anlayışın "güzel konuşmanın kâide ve kurallarını incelemeye" evrildiği görülmektedir. Müstakil bir disipline dönüşmeden önce ise belâgat konuları "beyân", "bedî‘", "şiir ve nesir kritiği” ve "fesâhat" gibi başlıklar altında incelenmiştir. ${ }^{87}$ Mu'tezile mensupları nahiv disiplininde olduğu gibi belâgat sahasında da bu ilmin üzerine inşâ edileceği temel kuralları belirlemeye yönelik çalışmalar yürütmüşlerdir. Nitekim Câhız (ö. 255/869) ve Rummânî (ö. 384/994) gibi Mu'tezilî dilcilerin “belâgat nedir?” sorusunun cevabını aradıkları ve belâgata dair birtakım kavramlar üretmek suretiyle bu alana katkı sundukları ifade edilmektedir. ${ }^{88} \mathrm{Mu}$ 'tezile'nin ilk dönem belâgat çalışmalarına katılmasında, mezhebin ileri gelenlerinin o zaman henüz nüve halinde bulunan belâgat bilgilerine, dinî bir boyut yüklemesi etkili olmuştur. Bu hususta Câhız (ö. 255/869) el-Beyân ve't-Tebyîn isimli eserinde mezhebin ileri gelenlerinden olan ve edebî vaazlarıyla tanınan Amr b. Ubeyd'in (ö. 144/761) belâgate dinî bir değer atfettiğine dair bazı rivâyetlere yer vermektedir. ${ }^{89}$

Mu'tezile için belâgata dair veriler, itikadî düşüncelerin ifade edilmesi açısından önemlidir. Şöyle ki mezhep mensuplarının girdikleri tartışmalarda başarı elde etmeleri, onların "güzel ve etkili söz söyleme" becerisini kullanabilmeleriyle yakından ilişkilidir. Bu hususta Sümâme b. el-Eşras (ö. 213/828), Nazzâm (ö. 231/845), Ebû Huzeyl el-Allâf (ö. 235/850), Ebû Ali el-Cübbâî (ö. 303/916) ve Ebu'l-Kâsım el-Ka‘bi (ö. 319/931) gibi Mu‘tezilî kimliği ile tanınan kişilerin belâgata dair nüansları bildikleri ve girdikleri tartışmalarda bu bilgilerden yararlandıkları dile getirilmektedir. ${ }^{90}$ Nitekim belâgat kabiliyeti, tartışma esnasında muhatabı ikna etmeye yarayan temel araçlardan biridir. İkna ise Mu‘tezile'nin

85 İbn Manzûr, Lisânu'l-'Arab, c. VIII, s. 419; İbn Fâris, Ebu'l-Hüseyn Ahmed, Mu 'cemu mekâyîsi'l-luğa, thk. Abdusselam M. Harun, Dâru'l-Fikr, yy. 1979, c. I, s. 301.

${ }^{86}$ Belâgat kavramı İngilizce'de "rhetoric" ve "eloquence" terimleriyle ifade edilmektedir. Bu terimlerden rhetoric belâgatın teorik; eloquence ise meleke özelliğini yansıtmaktadır. Bkz. Elias Anton - Edvar E., el-Kâmûsu'l-'Arabî (Modern Dictionary Arabic-English), elMatbaatü'l-Asriyye, Kahire tsz., s. 75.

87 Taşdelen, "Belâgat İlmi ve Tarihi”, s. 215-217.

${ }^{88}$ Sekkâkî’ye kadar belâgat alanına katkı sunan diğer Mu'tezilî dilciler için bkz: Zafer Kızıklı, “Arap Dilinde Retoriğin Bir Bilim Dalı Olarak Doğuşu, Gelişimi ve Öncüleri” ICANAS 38 Uluslararası Asya ve Kuzey Afrika Çalışmaları Kongresi Kitabl, Ankara 2007, s. 1018-1023. ${ }^{89}$ Câhız, el-Beyân ve't-Tebyîn, c. I, s. 114.

90 Nasrullah Hacımüftüoğlu, "Kelamcılar ile İslâm Felsefecilerinin Belâgat ve I'câz İlimlerinin Gelişmesinde Rolleri”, Atatürk Üniversitesi Ilahiyat Fakültesi Dergisi, 1991, sy. 10, s. 218. 
münazaralarda kullandığı cedel $^{91}$ metodunun nihâî bir gâyesidir. Mu'tezile mensupları bu açıdan yani belâgatı muhataplarını ikna etmek için kullanması nedeniyle antik çağ filozoflarından sofistlere benzetilmiştir. Atina sokaklarında gezip ikna kabiliyetlerini kullanarak kendi fikirlerini halka anlatmak için nutuklar veren Sofistler gibi, Mu'tezile'nin de Basra mescit ve sokaklarında benzer metotlarla insanları kendi saflarına çekmek için propagandalar yaptığı ifade edilmektedir. ${ }^{92}$

Mu'tezile'nin mezhebî aidiyetleri bağlamında yaptığı belâgî yorumlarda üzerinde durulması gereken en temel unsur mecâzdır. Sözlükte "bir yeri geçmek ve yol katetmek" gibi anlamlar ifade eden ${ }^{93}$ mecâz, belâgat ilminde "bir lafzın, hakikî anlamının dışında kullanılması" ${ }^{94}$ şeklinde tanımlanmaktadır. Sîbeveyhi (ö.180/796) başta olmak üzere ilk dönem dilcileri, eserlerinde her ne kadar bir 1stılah olarak mecâzdan bahsetmeseler de olgusal düzlemde mecâzın Arap dilinde varlığına dikkat çekmişlerdir. ${ }^{95}$ Mu'tezilî dilciler de mecâzın kavramlaşma sürecine ${ }^{96}$ katkı sağlamışlardır. Nitekim mecâz kelimesi, ıstılâhî olarak hakikatin karşılığı anlamında ilk defa Câhız (ö. 255/869) tarafindan el-Beyân ve’t-tebyîn isimli eserde kullanılmıştır.97 O, Kitâbu'l-Hayevân adlı eserinde ise mecâzın dilde farklı kullanımlara olanak veren (ittisa') bir özelliğe sahip olduğunu belirtmektedir. ${ }^{98}$ Kâdî Abdülcebbâr ise Kur'ân'ın Arap diliyle nâzil olduğuna dikkat çekerek Kur'ân'da hakikat anlamında kullanılan lafızların yanı sıra mecâzî ifadelerin de yer aldığını vurgulamıştır. ${ }^{99}$

Şunu belirtmek gerekir ki Arap dilinde mecâz, Mu'tezilî düşünürlerin elinde bir yandan kavramsal olarak sınırları çizilen bir belâgat öğesine dönüşmüş

\footnotetext{
${ }^{91}$ Cedel, münazara ilmine dair bir kavram olup, “tartışmada hasmın ileri sürdüğü fikirlerin iptali ve kendi düşüncesinin ispatı için karşılıklı yürütülen diyalog" ş̧eklinde tanımlanmaktadır. Bu konuda detaylı bilgi için bkz. Hasan Marulcu, Kelâm'da Nazar ve Münazara Âdabı, Dilruba Yayınları, Isparta 2018, s. 47-50.

92 İhsan Abbas, Târîhu'n-nakdi'l-edebî inde'l-'Arab (Nakdu'ş-şi 'ri), Dâru-s-Sekâfe, Beyrut 1983, s. 66-67; Nasrullah Hacımüftüoğlu, "Belâgat İlminin Gelişmesine Müessir Olan Kaynaklar”, Atatürk Üniversitesi Illahiyat Fakültesi Dergisi, 1993, sy. 11, s. 277.

93 İbn Manzûr, Lisânu'l- 'Arab, c. V, s. 326.

94 Teftâzânî, Sa'düddîn Mes'ûd b. Fahriddîn, Muhtasaru'l-me‘ânî, Salah Bilici Kitabevi, İstanbul tsz., s. 322-324; Fadl Hasan Abbâs, el-Belâğa, funûnuhâ ve efnânuhâ (ilmü'l-beyân ve'l-bedî‘), Dâru'l-Furkân, Ummân 2007, s. 140-142.

95 Sîbeveyhi (ö.180/796), el-Kitâb isimli eserinde Arap dilinde ifadelerin anlam boyutundaki genişlemelerini "ittisâ"," "si'atü'l-kelâm" ve "tevessü“" gibi genel kavramlarla ifade etmektedir. Sîbeveyhi, Ebû Bişr Amr b. Osman, el-Kitâb (Kitâbu Sîbeveyhi), thk. Abdüsselam Muhammed Harun, Mektebetü'l-Hânc1, Kahire tsz., c. I, s. 160, 167, 211-216.

${ }^{96}$ Bahsedilen sürece dair detaylı bilgi için bkz. Esat Sabırlı, Selefí Söylemde Mecaz Karşıtlı̆̆ (İbn Teymiyye'nin Kur'ân'da Mecaza Baklșl Özelinde), Aybil Yay., Konya 2017, s. 92-96.

${ }^{97}$ Kassâb, et-Türâsü'n-nakdî ve'l-belâgî, s. 335.

${ }^{98}$ Câhız, , Kitâbu'l-hayevân, c. V, s. 426.

99 Kâdî Abdülcebbâr, Fadlu'l-i 'tizâl s. 152.
} 
diğer yandan ise i'tizâlî yorumlarda kullanılan “te'vil silahı” şeklini almıştır. ${ }^{100}$ Şöyle ki mezhebin temel prensiplerine uyumlu âyetler muhkem kabul edilip hakikî anlamı üzere anlaşılırken; bahsedilen esaslara aykırı olan âyetler ise müteşâbih addedilmiş ve aynı konuda muhkem kabul edilen âyetler doğrultusunda hakikî anlamlarından çıkartılıp mecâzi manalara hamledilmiştir. ${ }^{101}$ Bu durumun da onların özellikle akla uygun bulmadıkları bazı âyetlerin tefsirinde yanılgıya düşmelerine neden olduğu ifade edilmektedir. ${ }^{102}$

Mu'tezile tevhid ilkesi bağlamında bir yandan Allah'1 cihet, mekân, cisim, hareket ve değişim gibi unsurlardan tenzih ederek Müşebbihe ve Mücessime gruplarına karşı haklı bir duruş sergilemekte diğer yandan daha önce kısaca temas ettiğimiz naslarda bildirilen ve âhirette mü'minler için gerçekleşecek ru'yetullâh'1 inkâr etmektedir. Söz konusu durum Mu'tezile'nin âhirette ru'yetin gerçekleşeceğini gösteren nasları müteşâbih olarak değerlendirmesine ve bu ifadeleri te'vil etmesine

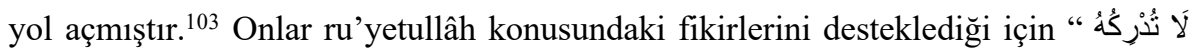

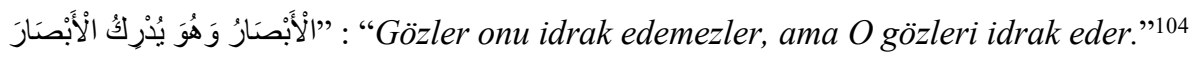
âyetini muhkem kabul etmişler; buna mukabil ru’yetullâhın gerçekleşeceğini gösteren " "O gün birtakım yüzler parlamaktadır; Rablerine bakmaktadırlar." 105 âyetinin ise müteşâbih olduğunu ileri sürmüşlerdir. Onlar dünyada fizikî olarak görme eyleminin, gözün görülmek istenen şeye doğru çevrilmesiyle oluştuğunu ve görülen şeylerin cismiyet vasfi taşıması durumunu ahirete de kıyas etmişlerdir. Diğer bir ifadeyle Mu'tezile ahirette gerçekleşecek ru'yetullah'1 şehadet âleminin varlık düzleminde ele almış bu nedenle Allah'ın

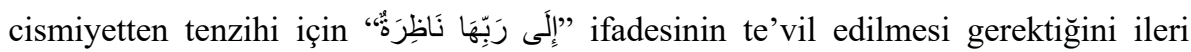

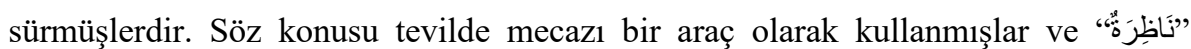

100 Nasr Hâmid, Ebû Zeyd, Tefsirde Akılcı Eğilim -Mu'tezile’ye Göre Kur'ân'da Mecâz Meselesi-, çev. Numan Konakl1-Nihat Uzun, Mana Yayınları, İstanbul 2015, s. 193, 366. Mecâz ve te'vil arasındaki irtibata dair detaylı bilgi için bkz. Ğusn, Mevkıfu'l-mütekellimîn mine'l-istidlâl, s. 500-501.

${ }^{101}$ Kâdî Abdülcebbâr, Șerhu'l-usûli'l-hamse, s. 600.

102 M. Vehbi Dereli, Kur'ân Tefsirinde Yanllgl Sebepleri ve Bunlardan Korunma Yollarl, (Yayınlanmamıs Doktora Tezi), Selçuk Üniversitesi Sosyal Bilimler Enstitüsü, Konya 2008, s. 72; Fethi Ahmet Polat, İslâm Tefsir Geleneğinde Akılcı Söyleme Yöneltilen Eleştiriler (Mu'tezîlî Zemahşerî'ye Eş 'arî İbnü'l-Müneyyir'in Eleştirileri), İz yayıncılık, İstanbul 2009, s. 55 .

103 Shehristânî, el-Milel ve'n-nihal, s. 39; Ahmed Emîn, Duha'l-İslâm, Dâru'l-Kütübi'lİlmiyye, Beyrut 2010, c. III, s. 24; Veysi Ünverdi, "Mu'tezile'nin İnanç Sistemi; Usûl-i Hamse/Bes İlke ve Arka Planı", Artuklu Akademi: Mardin Artuklu Üniversitesi İslâmi İlimler Fakültesi Dergisi, 2017, c. IV, sy. 2, s. 4.

104 En'âm 6/141.

105 Kıyâme 75/22-24. 
ifadesinin hakikat anlamında olmadığını bu ifadeye mecâz yoluyla "bekleyen" anlamının verilmesi gerektiğini söylemişlerdir. ${ }^{106}$

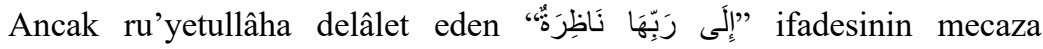
hamledilmesinde Mu'tezile'nin haklı bir gerekçesi bulunmamaktadır. Zira Ehl-i sünnet âlimlerinin de belirttiği gibi her ne kadar dünyada bizzat karşıllı̆ı olmasa da görme eyleminde esas olan mevcudiyettir ve nassın görmeye işaret etmesinden hareketle ru'yetullâh mümkündür. ${ }^{107}$ Şunu ifade etmek gerekir ki Mu'tezile tarafından ideolojik gayelerle bu kelimeye "bekleme" manasının yüklenmesi Kur'ân'ın kendisiyle indirildiği Arap dilinin gramatikal yapısına yapılan bir müdaheledir. Zira "نَظر" fiili "bekleme" manası taşıdığında mef"ûlünü, harf-i cer kullanılmadan almaktadır. ${ }^{108}$ Hâlbuki söz konusu ifade Kur'ân'da "bakmak" anlamında kullanılan diğer âyetlerde de olduğu gibi ${ }^{109}$ harf-i cer ile müte 'addî yapılmıştır. Ayrıca belâgat açısından "' "'Rablerine” ifadesinin, "bakan ve

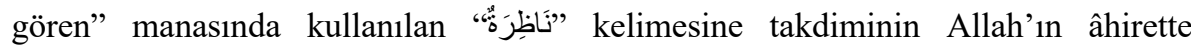
görüleceğini te'kid ettiği de ifade edilmelidir. ${ }^{110}$

Mu'tezilîler ru'yetullâh'ın yanı sıra haberî sıfatları bildiren âyetler karşısında da itikadî fikirlerini destekleyecek şekilde mecâzdan istifade etmişlerdir. Söz konusu haberî sıfatlardan biri de "istivâ"dır. ${ }^{111}$ Kâdî Abdülcebbâr (ö. 415/1025)

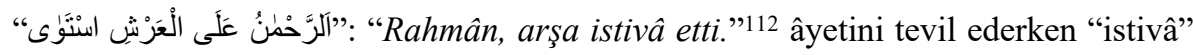
kelimesinin "bir yere yaslanmak ve yerleşmek" manası taşıdığııı ve bu anlamın da cisimler için geçerli olduğunu belirtmektedir. O, Allah'ın cismiyetten tenzih edilmesi gerektiğini düşünerek "istivâ" ifadesinin mecâza hamledilmesi gerektiğini dile getirmektedir. Kâdî Abdülcebbâr bu kelimenin mecâzî olarak "istîlâ" yani "üstün gelme ve hâkimiyeti altına alma" anlamı taşıdığını söylemekte ve bu kullanımın yaygın bir üslup olduğunu göstermek üzere Arap şiirinden şu beyti örnek vermektedir:

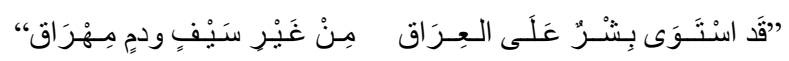

${ }^{106}$ Kâdî Abdülcebbâr, Ebu'l-Hasen b. Ahmed el-Hemedânî, Tenzîhu'l-Kur'ân 'ani 'l-metâ 'in, Dâru'l-Kütübi'l-İlmiyye, Beyrut 2008, s. 418-419; Marulcu, Kelâm-Belâgat İlişkisi, s. 61.

${ }^{107}$ Kamil Güneş, İslâmî Düșüncenin Şekillenişinde Akıl ve Nass - Bâkıllânî ve Kâdî Abdülcebbâr'da Kelâmullah Meselesi Örneği-, İnsan Yayınları, İstanbul 2003, s. 427. 108 “ 'نَظر fiilinin Kur'ân'daki harf-i cersiz kullanımları için bkz. Yâsîn 36/49; En'âm 6/158; Fâtır 35/43; Neml 27/35.

109 A'râf 7/198; Kâf 50/6; Âl-i İmrân 3/77.

110 Pişgin, Yasin, "Kur'an’a Göre Akıl-Gayb İlişkisi Bağlamında Mana Yönünde Yönünden Müteșabih Âyetlerin Tevili Meselesi”, Süleyman Demirel Üniversitesi İlahiyat Fakültesi Dergisi, 2012/2, sy. 29, s. 128.

111 İstivâ kavramıyla ilgili detaylı bilgi için bkz. Mustafa Güven, "Hakikat ve Mecâz Bağlamında Müteşabih Bir Kavram Olarak "İstivâ’”, Hikmet Yurdu, 2010, c. III, sy. 6, İbn Rüşd ö.s., s. 175-192.

112 Taha 20/5.

Turkish Academic Research Review - Türk Akademik Araştırmalar Dergisi 
“Bişr kılıç kullanmaksızın ve kan dökmeksizin Irak’a istivâ etti/egemen oldu."113

Kâdî Abdülcebbâr'ın “istivâ” kavramını mecâza hamletmesi, onun bu tür müteşâbih ifadeler karşısında müntesibi olduğu mezhebin genel karakteristiğini yansıtmakta diğer bir ifadeyle "tefvîz"i değil de “te’vîl”i esas aldığını ortaya koymaktadır. O, mecâza dayalı olarak yaptığı söz konusu teville bir yandan tenzihçi bir yaklaşım sergileyerek müşebbihe ve mücessime gibi grupların antropomorfik Tanrı anlayışlarına karşı çıkmakta, diğer yandan “istivâ”nın Zât-ı Kibriyâ hakkında simgelediği sırlı ve akıl üstü bağlamı aklîleştirmeye çalışmaktadır. ${ }^{114}$

Mezhep mensuplarının haberî sıfatların yanı sıra mecâzdan yararlandıkları diğer bir konu, halife Me'mûn döneminde siyasî bir zemine taşınarak halka zorla dayatılan halku'l-Kur'ân ideolojisidir. Mu'tezilîler Allah'ın kıdem sıfatı dışında ezelî bir sıfatının bulunmaması iddiasıyla O’nun ezelî kelâm sıfatına sahip olmasını inkâr etmişler bunun neticesinde Kur'ân'ın mahlûk olduğunu ileri sürmüşlerdir. ${ }^{115}$ Tevhid ilkesine aykırı olacağı endişesiyle sıfatların zât ile aynı şeyi ifade ettiğini söyleyen ve Kur'ân'ın mahlûk olduğu fikrini savunan Câhız'a (ö. 255/869) göre kelâm-1 ilâhî ses, telif, nazm ve hece harflerinden oluşan bir cisimdir. Ona göre Kur'ân'ın harflerden oluşması, onun bir başlangıcı ve sonu olduğunu göstermektedir ki başlangıcı ve sonu olan her şey mahlûktur. Bu düşünceden

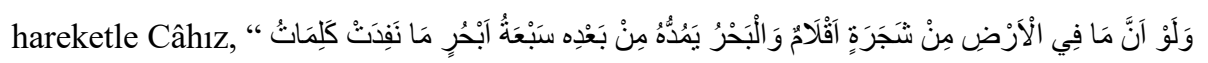
اله "Şayet yeryüzündeki ağaçlar kalem olsaydl, deniz de -ardından ona yedisi daha eklenmek üzere- mürekkep olsaydı yine de Allah'ın kelimeleri tükenmezdi."116 âyetindeki "Allah'ın kelimeleri” ifadesiyle, hakikî anlamın yani Kur'ân'ın kastedilmediğini ve bu ifadenin mecaza hamledilerek “Kur'ân'ın nimetleri,

113 Kâdî Abdülcebbâr, Şerhu'l-usûli'l-hamse, s. 226.

114 Pişgin, "Müteşâbih Âyetlerin Tevili Meselesi", s. 118, 123. Bu bağlamda diğer bir müteşâbih ifade olan "yed" "el" kelimesinin "kudret" anlamında kullanılmasına ilişkin değerlendirmeler için bkz. Marulcu, Kelâm - Belâgat İlişkisi, s. 57-58.

115 Şehristânî, el-Milel ve'n-nihal, s. 38-39; Güneş, İslâmî Düşüncenin Şekillenişinde Akll ve Nass, s. 219-220; Aydınl, Doğuşundan Büyük Selçuklulara Mu'tezile Ekolü, s. 259-261. Mu'tezile'nin ileri sürdüğü halku'l-Kur'ân ideolojisinin Allah'ın kelâm sıfatına sahip olmasına aykırı olduğu, bundan hareketle de Kur'ân'ın mahlûk kabul edilmesinin isabetli bir fikir olmadığı ortaya konulmuştur. İtikâdî içeriğe sahip söz konusu tartışmalar, Arap dili alanında yürütülen çalışmalar üzerinde de etkili olmuştur. Özellikle dillerin kökenine dair ileri sürülen tezlerde ve belâgat alanında yapılan çalışmalarda bu tartışmaların izlerine rastlanmaktadır. Bkz. Kees Versteegh, Landmarks in Linguistic Thought III, The Arabic Linguistic Tradition, Routledge, Oxon 1997, s. 107; Ali Ceyhan, Halku'l-Kur'ân Tartışmalarının Arap Dili Çalışmalarına Katkısı, (Yayınlanmamış Yüksek Lisans Tezi), Kahramanmaraş Sütçü İmam Üniversitesi Sosyal Bilimler Enstitüsü, Kahramanmaraş 2009, s. 49.

116 Lokmân 31/27. 
güzellikleri ve incelikleri hakkındaki sıfatlar" gibi bir anlam taşıdığını ileri sürmektedir. ${ }^{117}$

Mu'tezile'nin itikadî fikirlerini desteklemek üzere yaptığı mecâz yorumlarında dikkat çekmek istediğimiz husus mezhep mensuplarının Sîbeveyhi (ö. 180/796) ve Müberrred (ö. 286/900) gibi erken dönem dilcileri tarafindan dilsel bir olgu olarak değerlendirilen ve Abdülkâhir el-Cürcânî (ö. 471/1078-79) ile birlikte kavramsallaşan "mecâz-1 aklî"118 türünü yoğun bir şekilde kullanmalarıdır. Aklî mecâz, bir fiilin ya da fiil anlamı taşıyan isimlerin gerçek fâiline değil de; bir ilgi/mülâbeset ${ }^{119}$ gözetilerek fâilinden başka bir ögeye isnat edilmesidir. ${ }^{120}$ Mecâzın bu türüne aklî adı verilmesi, özne ve yüklem gibi cümle unsurları arasındaki ilişkiyi belirlemede aklın işlevsel bir konumda olduğunu göstermektedir. ${ }^{121}$ Öte yandan diğer mecâz türlerinde olduğu gibi aklî mecâzda da bir "karîne" bulunmalıdır. Sözü edilen karine, aklî mecâz bulunan ifadede isnadın hakikat üzere anlaşılmasına engel olmakta ve bu isnâdın mecâzî bir anlam taşıdığını ortaya koymaktadır. Mu'tezile ise aklî mecâzın varlığını ileri sürdüğü bazı âyetlerde i'tizâlî ön yargılarını aklî mecâzın karinesi olarak göstermekten geri durmamaktadır.

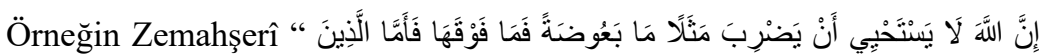

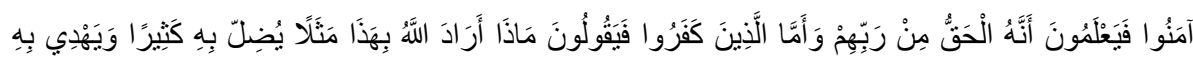

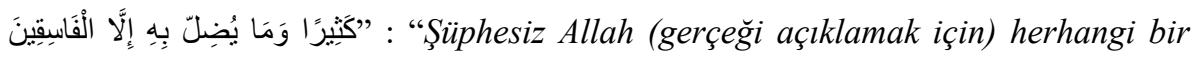
şeyi, bir sivrisineği hatta onun da ötesinde bir varlı̆̆l misal getirmekten çekinmez. Inananlar, bu misallerin Rablerinden gelen hak ve gerçek olduğunu pekâlâ bilirler. Inkâr edenler ise: Allah bu misali vermekle neyi kastediyor ki? derler. Allah onunla birçok kimseyi saptırır, birçoğunu da doğru yola ulaştırır. Fakat O, bununla sadece fâsıkları saptırır."122 âyetinde açık bir şekilde Allah’a isnat edilen "يُضِل" "Dalâlete düşürür/saptırır” fiilini zâhirî anlamından çıkarmak için aklî mecâza başvurmaktadır. Zemahşerî "Allah bir misal vermiş (sivrisinek örneği) bunun üzerine bir grup insan dalâlete düşmüş; diğerleri ise hidâyete ulaşmıştır. Dolayısıyla Allah söz konusu misali vermekle ilk grubun sapmasına, ikincisinin de hidâyetine

117 Câhız, Kitâbu'l-hayevân, c. I, s. 209. Konu hakkında detaylı bilgi için bkz. Marulcu, Kelâm-Belâgat İlişkisi, s. 51-52.

118 Ahmed Matlûb, Mu'cemu mustalahâti'l-belâğiyye ve tetavvurihâ, ed-Dâru'l-Arabiyye li'lMevsûat, Beyrut, 2006, s. 199-200.

119 Aklî mecâzın varlığından bahsedilirken üzerinde durulan en meşhur mülâbeset türleri şunlardır: Fâiliyye (mechûl fiilin veya ism-i mef'ûlün, fâile isnadı), mef'ûliyye (mâ‘lûm fiilin veya ism-i fâilin, mef ûle isnadı), masdariyye (fiilin, masdarına isnadı), zamâniyye (fiilin, zamana isnadı), sebebiyye (fiilin, sebebe isnadı) ve mekâniyye'dir (fiilin, mekâna isnadı). Konu hakkında daha kapsamlı bilgi için bkz. Kazvînî, Ebu'l-Meâlî Celâlüddîn, Telhîsu'lmiftâh, Salah Bilici Kitabevi, İstanbul tsz., s. 18.

120 Teftâzânî, Muhtasaru'l-me 'ânî, s. 45.

${ }^{121}$ Sekkâkî, Miftâhu'l- 'ulûm, s. 504; Abbâs, el-Belâğa, s. 140.

122 Bakara 2/26.

Turkish Academic Research Review - Türk Akademik Araştırmalar Dergisi 


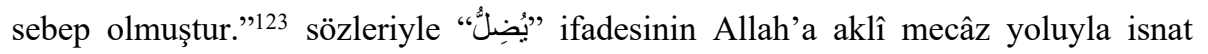
edildiğini dile getirmektedir. Ona göre buradaki mecâz, fiilin sebebe isnadı kabilindendir. ${ }^{124}$

Zemahşerî’nin söz konusu fiilin Allah'a isnadını, hakikat üzere anlamayı terk ederek aklî mecâza sarılmasının temelinde i'tizâlî amaçlar bulunmaktadır. Çünkü Mu'tezile Allah'ın, kulunu dalâlete düşürmesini kabîh bir fiil olarak yorumlamakta ve kabîh fiil işlemekten Allah'ın tenzih edilmesi gerektiğini düşünmektedir. Buna karşın Ebû Hayyân ve İbnü'l-Müneyyir gibi ilim adamları kâinattaki her şeyin yaratıcısının Allah olmasından hareketle; Allah'ın kulunu saptırmasının tıpkı hidâyet etmesi gibi onun yarattığı bir fiil olduğunu belirtmişler ve âyetteki isnadın hakikat olarak değerlendirilmesinin önünde bir mâni bulunmadığını ifade etmişlerdir. ${ }^{125}$

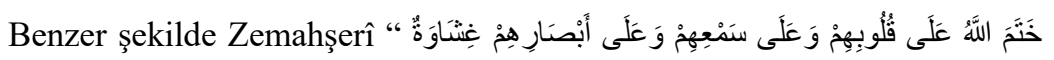
"Allah onların kalplerini ve kulakların mühürlemiştir, gözlerinin üzerinde de bir perde vardır. Onlar için büyük bir azap vardır." 126 âyetini tefsir

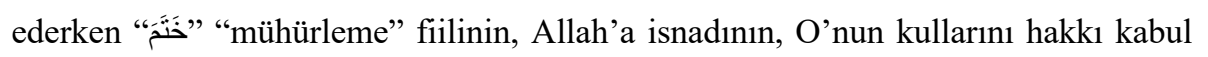
etmekten ve hakka ulaşmaktan engellediği anlamına geleceğini söylemektedir. Ardından müellif böyle bir eylemin kabîh bir fiil olacağını bu nedenle de Allah Teâlâ'nın bundan tenzih edilmesi gerektiğini ifade etmektedir. Zemahşerî “ “خَiَ” ifadesinde fiilin sebebine isnad edilmesine dayanan akl-i mecâz bulunduğunu ileri sürmektedir. Çünkü ona göre “" “خَ" filinin hakikî anlamdaki isnadı ya şeytana ya da kâfire yapılmalıdır. ${ }^{127}$ Zemahşerî’nin âyetin tefsirinde yaptığı bu izahlar, Kâdî Beydâvî (ö. 685/1286) tarafından i'tizâlî görüşleri benimseyenlerin ileri sürdükleri te'viller arasında zikredilmektedir. ${ }^{128}$ Ayrıca İbnü'l-Müneyyir, âyetteki isnadın mahiyetine ilişkin kullandığı ifadelerle Zemahşer̂̂’nin "âyetin sarih anlam zirvesinden te'vîl vadisine" indiğini söylemiş ve onun bu konuda aklî ve naklî delillere muhalefet ettiğini belirtmiştir. ${ }^{129}$

İncelenen örneklerde de görüldüğü gibi Mu'tezile, müteşâbih kabul ettiği âyetlerin tevilinde Arap dilindeki mecâz olgusundan yararlanmıştır. Bu hususta mezhep mensuplarının i'tizâlî fikirlerinden hareketle mecâzda bulunması zorunluluk

\footnotetext{
123 Zemahşerî, el-Keşşâf $f$, c. I, s. 123.

124 Bkz. Zemahşerî, el-Keşşâf, c. I, s. 123.

125 İbnü'l-Müneyyir, el-İnsâf, c. I, s. 123; Ebû Hayyân, el-Bahru'l-muhît, c. I, s. 270.

${ }^{126}$ Bakara 2/7.

127 Zemahşerî bu âyetin tefsirinde mecâz-1 aklî dışında diğer belâgat unsurlarından da istifade etmektedir. Bkz. Zemahşerî, el-Keşşâf, c. I, s. 60.

128 Beydâvî, Envâru't-tenzîl ve esrâru't-te'vîl, c. I, s. 23.

129 Detaylı bilgi için bkz. İbnü'l-Müneyyir, el-İnsâf, c. I, s. 57-59.
} 
arz eden "karîne" tespitinde bulundukları görülmektedir. Sözü edilen durum da onların mezhebî düşüncelerini haklı çıkarmak maksadıyla Arap diline yaklaştıklarını ortaya koymaktadır. Mu'tezile'nin itikadî fikirlerini ortaya koyarken kullandığı dilsel argümanlar âyetlerin farklı okunuş şekillerinde de bulunmaktadır.

\subsection{Kıraat Farklılarına Dayanan Dilsel İzahlar}

Kur'ân'ın korunarak nesilden nesle intikali hususunda Müslümanların son derece titiz ve gayretli olduklarının bir göstergesi kabul edilen kıraatlerde ${ }^{130}$ âyetlerdeki kelimelerin farklı okunuş şekilleri, râvilerine nisbet edilerek incelenmektedir. ${ }^{131}$ Kıraatler sıhhat bakımından bazı şartlara göre tasnif edilmiştir. $\mathrm{Bu}$ şartların arasında kıraatin imlâ olarak Hz. Osman'a nispet edilen mushaf hattına mutabık olması ve bir yönüyle bile olsa dil kurallarına uygunluk arz etmesi gibi dil alanını ilgilendiren birtakım kriterler de bulunmaktadır. ${ }^{132}$ Ayrıca kıraatlerde kelimelerin malum-meçhul, müfred-cemi ve muhâtab-gâib gibi farklı okunuş keyfiyetleri de Arap diliyle ilişkilidir. ${ }^{133}$ Belirtilen hususlar kıraatin Arap dilinden bağımsız bir alan olmadığını ortaya koymaktadır.

Dilci kimliği ile ön plana çıkan Mu'tezile mensupları da kıraat alanıyla ilgilenmişlerdir. Mu'tezile'nin kıraat olgusuna yaklaşımının incelendiği çalışmalarda mezhep mensuplarının itikadî görüşlerini temellendirme kaygısıyla eklektik bir yaklaşım benimsedikleri; onların kimi zaman mütevâtir kıraatler arasında tercihte bulundukları kimi zaman ise şâz kıraatleri, mütevâtir kıraatlere önceledikleri ifade edilmektedir. ${ }^{134}$ Hatta bu hususta onların bazı okuyuş biçimleri ihdâs etmeleri iddiasıyla eleştirilerildikleri dahi görülmektedir. ${ }^{135}$ Mezhep mensuplarının itikadî amaçlarla kullandıkları kıraatlerin bütünüyle incelenmesi makalemizin kapsamı

${ }^{130} \mathrm{Bu}$ konuda ilim adamlarının Kur'ân'daki kelimelerin işmâm, imâle ve teshil gibi telaffuz şekillerini ayrıntılı bir şekilde tespit ettikleri, şifahi olarak aktardıkları ifade edilmektedir. Bkz. Abdurrahman Çetin, “Kur'ân'ın Farklı Yorumlanmasında Kıraatlerın Rolü”, Diyanet İlmi Dergi, 2001, c. XXXVII, sy. 4, s. 98.

131 İbnü'l-Cezerî, Ebu'l-Hayr Şemsüddin Muhammed, Müncidü'l-mukri'în ve mürşidü'ttâlibîn, Dâru'l-Kütübi'l-İlmiyye, Beyrut 1999, s. 9.

132 Suyûtî, Ebu'l-Fazl Celâlüddîn, el-İtkân fì 'ulûmi'l-Kur'ân, thk. Şuayb Arnavut, Müessestü'r-Risâle, Beyrut 2008, s. 163-176; Muhsin Demirci, Tefsir Usûlü, İFAV Yayınları, İstanbul 2013, s. 118-119; Nazife Nihal İnce, Arap Dili İlimleri İle Tecvit İlmi Arasındaki Münasebet, İlâhiyat Yayınları, Ankara 2018, s. 90.

133 Mustafa Altundağ, "Sahih Kırâatlerin Arap Lehçeleriyle İlișkisi Üzerine", Marmara Üniversitesi İlahiyat Fakültesi Dergisi, 2001, sy. 20, s. 47-48.

134 Zehebî, et-Tefsîr ve'l-müfessirûn, c. I, s. 268-269.

135 Batalyevsî, Ebû Muhammed Abdullâh, el-İnsâf fi't-tenbîhi ale'l-me 'ânî ve'l-esbâbi'lletî evcebeti'l-ihtilâf beyne'l-müslimîn fî ârâihim, thk. Muhammed Ridvân ed-Dâye, Dâru'l-Fikr, Beyrut 1987, s. 159-160.

Turkish Academic Research Review - Türk Akademik Araştırmalar Dergisi 
dışında kalmaktadır. Bu nedenle söz konusu kıraatlerin dile ilişkin boyutları örnekler üzerinden ele alınacaktır.

Arap dilinde isimler, fiil cümlelerinde kimi zaman i'râb bakımından fâil ya da mef ûl olarak değerlendirilmeye imkân tanıyan bir şekilde bulunmaktadır. Bu durum da doğal olarak cümlede ifade edilmek istenilen anlamın değişmesine neden olmaktadır. Mu'tezile "' "Allah, Mûsâ ile gerçekten konuştu.”'136 âyetinde bahsedilen anlam farklılaşmasından yararlanmaktadır. Şöyle ki mütevâtir kıraatlerin tamamı âyetteki lafza-i celâlin merfu okunması hususunda görüş birliği

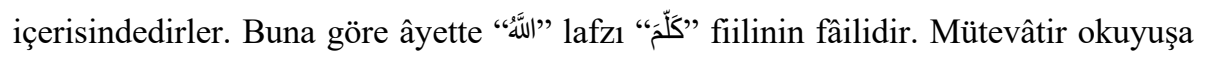
göre anlam ise mealini verdiğimiz şekilde ortaya çıkmakta ve Allah Teâlâ'nın kelâm sıfatına sahip olduğunu açık bir şekilde ortaya koymaktadır. Fakat Mu'tezile daha önce de değindiğimiz üzere "teaddüd-i kudemâ" iddiasıyla Allah Teâlâ'nın kelam sıfatına sahip oluşunu kabul etmemektedir. Sözü edilen görüş İbn Cinnî’nin (ö. 392/1002) Allah lafzının mansûb olarak okunduğu “ sَّeklindeki İbrâhim en-Nehâ̂’ye (ö. 96/714) ait şâz kıraati tercih etmesinde etkili olmuştur.

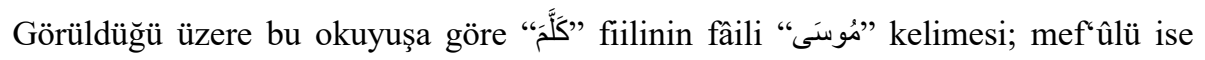
lafza-i celâl olarak belirlenmektedir. Bahsedilen âyette cümledeki fail ve mef'ûl arasındaki değişim, "Mûsa, Allah ile konuştu." şeklinde bir manayı ortaya çıkarmakta ve bu anlam i'tizâlî görüşlere de uyum göstermektedir. ${ }^{137}$

Kaynaklarda İbn Cinnî’nin öncelediği şâzz kuraatle ilgili şöyle bir olay nakledilmektedir: Bir gün kıraat imamlarından Ebû Amr b. Alâ’ya (ö. 154/771),

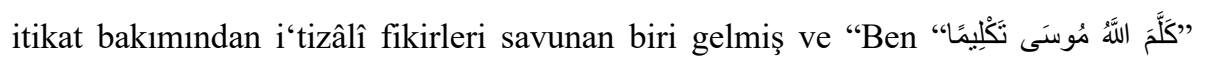
âyetinde fâilin Allah değil de Mûsâ olması için lafza-i celâli mansûb bir şekilde okumanı istiyorum." demiştir. Ebû Amr bu istek üzerine "Hadi bu âyeti senin

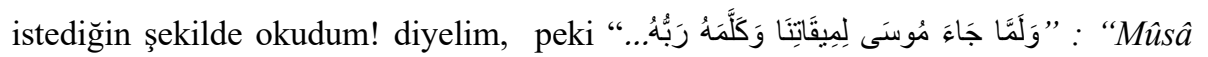
belirlediğimiz vakit gelip de Rabbi kendisine konuşunca..."138 âyetinde ne yapacaksın ki?!"” şeklinde bir cevap vermiştir. Söz konusu kişi, Ebû Amr'ın verdiği bu cevap karşısında söyleyecek bir ifade bulamamıştır. ${ }^{139}$

Mu'tezile'nin itikadî görüşleri nedeniyle mütevâtir kıraati bırakıp şâz kıraate başvurduğu diğer bir örnek ise “" “Şüphesiz biz her şeyi

136 Nisâ 4/164.

137 İbn Cinnî, Ebu'l-Feth Osmân, el-Muhteseb fî tebyîni vucûhi şevâzzi'l-kırââti ve'l-îdâhi anhâ, thk. Ali en-Necdî Nâsıf, Abdulhalîm en-Neccâr, Abdülfettah İsmâîl Şelebî, Dâru Serkîz, yy. 1986, c. I, s. 204; Bayram Demircigil, “İbn Cinnî’nin el-Muhteseb'inde Şâz Kıraatlere Yaklaşımı", Sakarya Üniversitesi İlahiyat Fakültesi Dergisi, c. XIX, sy. 35, s. 9697.

138 A'râf 7/143

139 İbnu Ebi'l-İz, Şerhu'l- 'Akîdeti't-Tahâviyye, c. I, s. 177. 
bir ölçüye göre yarattık. ”140 âyetidir. Mütevâtir kıraatlerin tamamında âyetteki “"كُ" kelimesi, mansub olarak yer almaktadır. Bu okuyuş şekline göre “"كُ" ifadesi, mezkûr fiilden anlaşılan mahzûf “خَ”َ' fiilinin mef'ûlü olarak i'râb edilmektedir. ${ }^{141}$ Söz konusu i'râb değerlendirmesine göre âyetin anlamı, meâli verilen şekilde ortaya çıkmakta ve bu ifade âlemdeki tüm oluş ve eylemlerin mahlûk, bunların yaratıcısının ise sadece Allah olduğunu göstermektedir. Bu anlam ise Mu'tezile'nin ef'âl-i ibâd konusundaki düşüncelerine ters düşmektedir. Söz konusu nedenle mezhep mensupları, insanın gerçekleştirdiği eylemleri âyetin mefhumundan çıkarmak için Ebu's-Semmâl'e nisbet edilen şâz bir okuyuşa itibar etmişlerdir. ${ }^{142}$ Bahsedilen şâz kıraatin tercih edilmesini savunanlardan İbn Cinnî, bu hususta şu ifadeleri kullanmaktadır:

Her ne kadar ilim adamlarının çoğunluğu " “"ُّل ifadesinin mansûb okuyuş şeklini tercih etse de bu kelimenin merfu okunması mansûb okunmasından daha kuvvetlidir. Merfu okuyuş biçimine göre ilgili kelime, mübtedâ

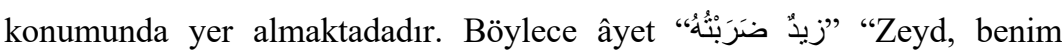
dövdüğüm kimsedir." ifadesine de benzerlik göstermektedir. Bu gibi ifadelerde ref'a seçimi, el-Kitâb sahibinin (Sîbeveyhi) yanı sıra birçok dilcinin görüşüdür. ${ }^{143}$

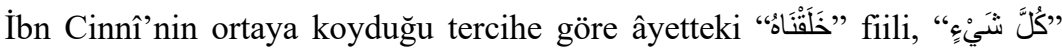
ifadesinin sıfatı olmaktadır. Dolayısıyla âyet her şeyin değil de, Allah'ın yarattığı şeylerin bir takdir üzere olduğunu bildirmekte; diğer bir deyişle " ifadesinden bazı istisnâların çıkarılmasına olanak sağlamaktadır. Nihayetinde âyet Mu'tezile aleyhine bir delil olmaktan çıkmakta ve mezhebî fikirlerle uyumlu hale gelmektedir. İbn Cinnî’nin mütevâtir kıraati devre dışı bırakarak şâz kıraati öncelemesinde i'tizâlî görüşleri değil de gramatik gerekçeleri kullanması ise dikkat çekicidir. Fakat İbn Cinnî’nin öne sürdüğü bu tercihin, diğer nahivciler tarafindan onaylanmadığı ve genel geçer bir doğru olarak da telakki edilmediği belirtilmelidir. Örneğin içlerinde İbn Mâlik'in de bulunduğu dilciler, mütevâtir okunuş şekline mebni âyetin umumî bir anlam ifade ettiğini; ref okuma biçiminde ise bu mananın

140 Kamer 54/49.

141 “"sُ" kelimesinin mansûb okunuş biçimiyle ilgili diğer i'râb çözümlemeleri için bkz. Seyf, Muhammed b. Abdillâh, el-Eseru'l- 'akdî fî teaddüdi't-tevcîhi'l-i 'râbî li âyâti'l-Kur'âni'lKerîm, Dâru't-Tedmuriyye, Riyad 2008, c. II, s. 580-586.

142 Semin Halebî, ed-Dürrü'l-mesûn, c. X, s. 146-147; Marulcu, Kelâm-Belâgat İliskisi, s. 133; Mehmet Adıgüzel, "Kıraat Farklılıklarından Kaynaklanan Bazı Kelâmî İhtilaflar", Atatürk Üniversitesi İlahiyat Fakültesi Dergisi, 2007, sy. 28, s. 188-191.

143 İbn Cinnî, el-Muhteseb, c. II, s. 300.

Turkish Academic Research Review - Türk Akademik Araştırmalar Dergisi 
ortadan kalktığına dikkat çekmişler ve anlam boyutunda ortaya çıkan değişim nedeniyle ilgili kelimenin mansûb okunmasını tercih etmişlerdir. ${ }^{144}$

Mu'tezile'nin ef'âl-i ibâd konusundaki fikirlerine aykırı bir durum

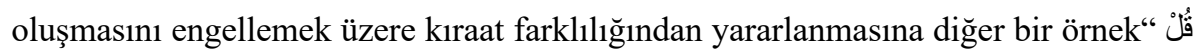

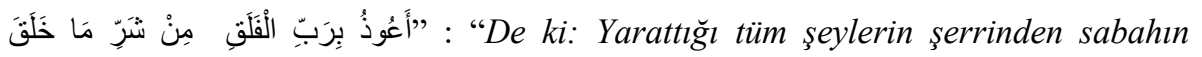
Rabbine sığınırım." ${ }^{145}$ âyetidir. ${ }^{146} \mathrm{Bu}$ hususta İbn Atıyye (ö. 541/1147) Allah Teâlâ’nın şerri yaratmadığını ileri süren Amr b. Ubeyd (ö. 144/761) başta olmak üzere Mu'tezile mensuplarının âyetteki "şerr" kelimesini tenvinle okuduklarını ve "mâ" kelimesini de nefy/olumsuzluk anlamına hamlettiklerini söylemektedir. Bu tercihe göre âyetin meali "De ki: Yaratmadığı şerden Sabahın Rabbine sığınırım." şeklinde ortaya çıkmaktadır. İbn Atıyye mezhep mensuplarının ileri sürdüğü söz konusu kıraatin, aslında mezhebî düşünceleri haklı çıkarmak gayesiyle kurgulandığını bu nedenle de reddedilmesi gerektiğini ifade etmektedir. Çünkü

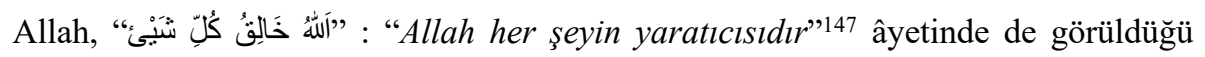
üzere kâinattaki her şeyin yaratıcısı olduğunu açık bir şekilde bildirmektedir. ${ }^{148}$

Mu'tezile'nin mezhebî aidiyetler bağlamında kıraat farkll1ıklarından

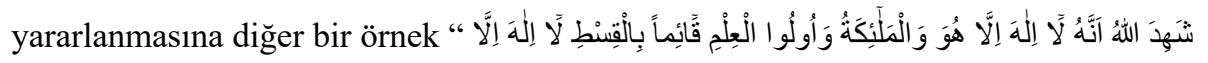
هُ "Allah, melekler ve ilim sahipleri O'ndan başka tanrı olmadığına adaletle şahitlik ettiler. (Evet) O'ndan başka tanrı yoktur; O mutlak gü̧ ve hikmet sahibidir. Hiç şüphe yok ki; Allah katında din, İslâm'dır...”149

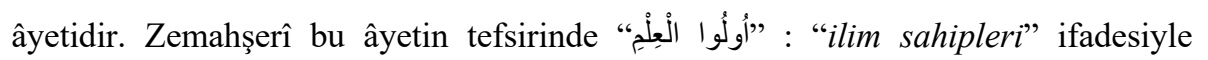
kastedilen kimselerin Mu'tezilî bilginler olduğunu söylemektedir. Ardından o, âyette

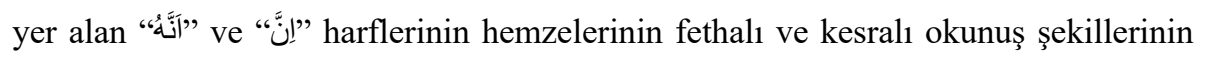
gramatik uzantılarını detaylı bir şekilde ele almaktadır. Burada dikkat çeken husus müellifin hemzenin okunuşa bağlı olarak ortaya çıkan anlamlarda İslâm'ın aslında Mu'tezile'nin tevhid ve adalet prensiplerinden ibaret olduğunu vurgulamasıdır.

144 İbn Mâlik, Ebû Abdillâh Cemâlüddîn Muhammed, Şerhu't-Teshîl, thk. Abdurrahmân esSeyyid, Muhammed Bedevî el- Mahtûn, Dâru Hicr, yy. tsz., c. II, s. 142; Ebu'l-Kâsım Abdurrahmân b. Abdillâh b. Ahmed el-Has'amî es-Süheylî, Netâicü'l-fiker fi'n-Nahv, thk. Ali Muhammed Muavvaz- Âdil Ahmed Abdulmevcûd, Dâru'l-Kütübi'l-îlmiyye, Beyrut 1992, s. 336.

${ }^{145}$ Felak 113/1-2.

${ }^{146}$ Batalyevsî, el-Insâff fi 't-tenbîhi ale 'l-me 'ânî, s. 159-160.

147 Zümer 39/62.

148 Ebû Hayyân, el-Bahru'l-muhît, c. VIII, s. 533.

149 Âl-i İmrân 3/18-19. 
Ayrıca onun kendi mezhebi dışındaki bütün ekollerin İslâm dairesi dışında olduğunu iddia etmesi de mezhebî taassubundan kaynaklandığı ifade edilmektedir. ${ }^{150}$

Görüldüğü üzere Mu'tezile sadece mütevâtir kıraatlerden değil aynı zamanda âyetlerin diğer okunuş şekillerinden de yararlanmıştır. Bu durum onların söz konusu kıraatlerin farklı dilbilimsel çıkarımlara imkân tanıyan yapısını gözettiklerini ve mezhebî düşüncelerini desteklediği ölçüde bu hususu kullandıklarını ortaya koymaktadır.

\section{Sonuc}

Mu'tezile, Kur'ân âyetlerini inanç sistemlerinin temelini oluşturan "usûl-i hamse" doğrultusunda anlamış ve mezhebî fikirleriyle çelişen âyetleri birtakım aklî yöntemler kullanarak tevile başvurmuş̧tur. Söz konusu tevillerde Arap dilinin, mezhep mensupları tarafından bir yorum enstrümanı olarak kullanıldığı görülmektedir. Onlar dilsel referanslar aracıllğıyla i‘tizâlî düşüncelerini Kur’ân'a onaylatma gibi mezhebî bir amaç taşımışlardır.

Mu'tezile mensuplarının itikadî gerekçelerle kullandıkları dilsel argümanlar genel hatlarıyla gramatik tahliller, belâgî yorumlar ve kıraat farklılıklarına dayanan dilsel izahlar şeklinde tasnif edilebilir. Onların mezhebî aidiyetleri bağlamında başvurdukları gramatik izahlar genellikle âyetlerin farklı i'râb çözümlemelerine dayanmaktadır. Bununla birlikte kimi harflere ideolojilerine uygun anlamlar yüklediklerine de tanık olunmaktadır. Bahsedilen gramatik açıklamalarda Mu'tezile kimi zaman Arap dilinin imkânlarından istifade etmiş; kimi zaman ise dilin tabiatında olmayan zorlama olarak kabul edilebilecek birtakım yorumlara başvurmuştur.

Mu'tezile için belâgata dair veriler, itikadî fikirlerin ortaya konulması açısından önemli kabul edilmiştir. Mezhep mensuplarının i‘tizâlî aidiyetler bağlamında başvurdukları en temel belagat unsuru mecâzdır. Arap dilinde mecâz, Mu'tezilî düşünürlerin elinde bir yandan dilsel olarak sınırları çizilen bir kavram halini almış diğer yandan ideolojik fikirlerde kullanılan bir yorum aracına dönüşmüştür. Onlar akla uygun bulmadıkları bazı âyetlerde i 'tizâlî ön yargılarını hakikî mananın anlaşılması önündeki "karine" olarak göstermek suretiyle bahsedilen ifadeleri mecâza hamletmişlerdir.

150 Zemahșerî, el-Keşşâf, c. I, s. 339-340. Krş. Râzî, Mefâtîhu'l-ğayb, c. VII, s. 223; İbnü’lMüneyyir, el-İnsâf, c. I, s. 340.

Turkish Academic Research Review - Türk Akademik Araştırmalar Dergisi https://dergipark.org.tr/tr/pub/tarr 
Görülüyor ki mezhep mensupları gerek nahvî gerek belâgî izahlarda olsun Arap dilini usûl-i hamseye hizmet eden bir araç olarak görmüşlerdir. Bu durum onların eserlerinde yer verdikleri kimi dilsel tahlilleri, nastan hareketle düşünceyi kurma gibi bir gaye ile yapmadıklarını bunun yerine söz konusu dilsel analizleri, ideolojik amaçlarla kullandıklarını ortaya koymaktadır.

Çalışmamızın Mu'tezilî gelenekteki dil düşünce arasındaki ilişkinin sorgulanmasına katkı sağlayacağı bununla birlikte sözü edilen bağın analiz edilip tartışılacağı diğer çalışmalar için fikir vereceği de söylenilebilir.

\section{Kaynakça}

Abbâs, Fadl Hasan, el-Belâğa, funûnuhâ ve efnânuhâ (ilmü'l-beyân ve'l-bedî'), Dâru'l-Furkân, Ummân 2007.

Abbas, İhsan, Târîhu'n-nakdi'l-edebî inde'l-'Arab (Nakdu'ş-şi 'ri), Dâru-s-Sekâfe, Beyrut 1983.

Adıgüzel, Mehmet, “Kıraat Farklılıklarından Kaynaklanan Bazı Kelâmî İhtilaflar”, Atatürk Üniversitesi İlahiyat Fakültesi Dergisi, 2007, sy. 28, ss. 165-200. Ahmed Emîn, Duha'l-İslâm, Dâru'l-Kütübi'l-İlmiyye, Beyrut 2010.

Ahmed Matlûb, Мu'cemu mustalahâti'l-belâğiyye ve tetavvurihâ, ed-Dâru'lArabiyye li’l-Mevsûat, Beyrut, 2006.

Altundağ, Mustafa, "Sahih Kırâatlerin Arap Lehçeleriyle İlişkisi Üzerine”, Marmara Üniversitesi İlahiyat Fakültesi Dergisi, 2001, sy. 20, ss. 23-48.

Atâullah, Hidır Ahmed, Beytü'l-hikmeti fì 'asri'l- 'Abbâsiyyîn, Dâru'l-Fikri’l-‘Arabî, Kahire tsz.

Avcı, Necati, “İslâm Dünyasında Kütüphaneciliğin Doğuşu ve İlk Örnekleri (Beytü'l-Hikme'den Dâru'l-Hikme'ye)", Eskişehir Osmangazi Üniversitesi Sosyal Bilimler Dergisi, 2000, ss. 5-14.

Aydınlı, Osman, "Mu'tezile Ekolü: Teşekkülü, İlkeleri ve İslâm Düşüncesine Katkıları", Marife: Dini Araştırmalar Dergisi [Bilimsel Birikim], 2003, c. III, sy. 3, Mu'tezile Özel Sayısı, ss. 27-54.

, Doğuşundan Büyük Selçuklulara Mu’tezile Ekolü, Doğuşundan Büyük Selçuklulara Mu'tezile Ekolü: Tarihi ve Öğretisi, Endülüs Yayınları, İstanbul 2018.

Bahşi, Turan, “Arapçada "Lahn”ın Dil Çalışmalarına Etkisi”, Turkish Academic Research Review (TARR), y1l:5 say1: 4. 
İbn Mâlik ve Nahiv İlmi Açısından el-Elfiyye Adlı Eseri, (Yayınlanmamış

Yüksek Lisans Tezi), Akdeniz Üniversitesi Sosyal Bilimler Enstitüsü, Antalya 2012.

Batalyevsî, Ebû Muhammed Abdullâh b. Muhammed, el-İnsâf fi't-tenbîhi ale'lme 'ânî ve'l-esbâbi'lletî evcebeti'l-ihtilâf beyne'l-müslimîn fî ârâihim, thk. Muhammed Rıdvân ed-Dâye, Dâru'l-Fikr, Beyrut 1987.

Beydâvî, Nâsırüddîn Ebû Saîd, Envâru't-tenzîl ve esrâru't-te'vîl, Dâru'l-Kütübi'lİlmiyye, Beyrut 2006.

Câhız, Ebû Osmân Amr b. Bahr, Kitâbu'l-hayevân, thk. Abdüsselâm Muhammed Harun, yy. 1965. , el-Beyân ve't-Tebyîn, thk. Abdusselam Muhammed Harun, yy. tsz. , el-Muhtâr fi'r-reddi 'ale’n-nasârâ, thk. Muhammed Abdullah Şerkâvî, Daru'l-Cîl, Beyrut 1991.

Cevherî, Ebû Nasr İsmâîl b. Hammâd, es-Sihâh -Tâcu'l-luğa ve sihâhu'l-'Arabiyye-, (nşr. Muhammed Tâmir-Enes Muhammed eş-Şâmî-Zekeriyyâ Câbir Ahmed), Dâru'l-hadîs, Kahire 2009.

Ceyhan, Ali, Halku'l-Kur'ân Tartışmalarının Arap Dili Çalışmalarına Katkısı, (Yayınlanmamış Yüksek Lisans Tezi), Kahramanmaraş Sütçü İmam Üniversitesi Sosyal Bilimler Enstitüsü, Kahramanmaraş 2009.

Cürcânî, Ebu'l-Hasen es-Seyyid eş-Şerîf, Kitâbu't-ta 'rifât, thk. Âdil Enver Hızır, Dâru'l-Ma'rife, Beyrut 2007.

Çelebi, İlyas, "Sıfat”, TDV İslâm Ansiklopedisi, İstanbul 2009, c. XXXVII, ss. 100106.

Çetin, Abdurrahman, “Kur'ân'ın Farklı Yorumlanmasında Kıraatlerın Rolü”, Diyanet İmi Dergi, 2001, c. XXXVII, sy. 4, ss. 77-100.

Dayf, Şevkî, el-Belăğa: Tetavvur ve Tarîh, Dâru'l-Meârif, Kahire tsz.

Demirci, Muhsin, Tefsir Usûlü, İFAV Yayınları, İstanbul 2013.

Demirci, Mustafa, “Antik Bilim ve Düşünce Mirasının İslâm Dünyasına Tercümesinde Abbasilerin Kurduğu Beytü'l-Hikme'nin Rolü’, Muhafazakâr Düşünce Dergisi, 2015, sy. 44, ss. 99-119.

Demircigil, Bayram, “İbn Cinnî’nin el-Muhteseb’inde Şâz Kıraatlere Yaklaşımı”, Sakarya Üniversitesi Illahiyat Fakültesi Dergisi, 2017, c. XIX, sy. XXXV, ss. 77-101.

Dereli, M. Vehbi, Kur'ân Tefsirinde Yanılgı Sebepleri ve Bunlardan Korunma Yolları, (Yayınlanmamış Doktora Tezi), Selçuk Üniversitesi Sosyal Bilimler Enstitüsü, Konya 2008.

Durmuş, İsmail, “Hazif”, TDV İslâm Ansiklopedisi, İstanbul, 1998, c. XVII, ss. 124.

Turkish Academic Research Review - Türk Akademik Araştırmalar Dergisi https://dergipark.org.tr/tr/pub/tarr 
Ebû Hayyân, Muhammed b. Yûsuf el-Endelüsî, el-Bahru'l-muhît, Dâru'l-Kütübi'lİlmiyye, Beyrut, 1993.

Ebu'l-Bekâ, Eyyûb b. Mûsâ el-Hüseynî el-Kefevî, el-Külliyyât - Mu'cemun fílmustalahâti ve'l-furûki'l-luğaviyye, thk. Adnan Derviş - Muhammed elMisrî, Müessesetü’r-Risâle, Beyrut 1998.

Elias Anton - Edvar E., el-Kâmûsu'l- 'Arabî (Modern Dictionary Arabic-English), el-Matbaatü'l-Asriyye, Kahire tsz.

Emîl Bedî Yakûb, Mevsûatu 'ulûmi'l-luğati'l- 'Arabiyye, Dâru'l-Kütübi'l-İlmiyye, Beyrut 2006, c. II, s. 296.

Erdem, Gazi, “İslâm Kültür Tarihinin İlk İlimler Akademisi: Beytü’l-Hikme”, Dini Araştırmalar Dergisi, y1l: 2013, c. XVI, sy. 42.

Fück, Johann, el-'Arabiyye -dirâsâtün fi'l-luğa ve'l-lehecât ve'l-esâlîb-, (çev. Abdulhalim en-Neccâr), Mektebetü'l-Hancî, Kahire, 1952.

Goldziher, Ignaz, Klasik Arap Literatürü, (çev. Rahmi Er-Azmi Yüksel), Vadi Yayınları, Ankara 2012.

Gölcük, Şerafeddin, "Rızık”, TDV İslâm Ansiklopedisi, İstanbul 2008, c. XXXV, ss. 73-74.

Güman, Osman, Nahiv ve Fıkıh Usûlü İlişkisi, İSAM Yayınları, Ankara 2017.

Güneş, Kamil, İslâmî Düşüncenin Şekillenişinde Akıl ve Nass - Bâklllânî ve Kâdî Abdülcebbâr'da Kelâmullah Meselesi Örneği-, İnsan Yayınları, İstanbul 2003.

Güven, Mustafa, "Hakikat ve Mecâz Bağlamında Müteşâbih Bir Kavram Olarak "İstivâ"”, Hikmet Yurdu, 2010, c. III, sy. 6, ss. 175-192.

Ğusn, Suleyman b. Salih b. Abdilaziz, Mevkrfu'l-mütekellimîn mine'l-istidlâl bi nusûsi'l-Kitâb ve's-sünne, Dâru'l-'Âsıme, Riyad 1996.

Hacımüftüoğlu, Nasrullah, "Belâgat İlminin Gelişmesine Müessir Olan Kaynaklar", Atatürk Üniversitesi Illahiyat Fakültesi Dergisi, 1993, sy. 11, ss. 268-298. , "Kelamcılar ile İslâm Felsefecilerinin Belâgat ve İ'câz İlimlerinin Gelişmesinde Rolleri”, Atatürk Üniversitesi Ilahiyat Fakültesi Dergisi, 1991, sy. 10, ss. 208-220.

Hayyât, Ebu'l-Hüseyn Abdürrahîm b. Muhammed b. Osmân, Kitâbu'l-intisâr ve'rreddi 'alâ İbni'r-Râvendî el-mulhid, nşr. H. Samuel Nyberg, Mektebetü'd-Dâri'l-Arabiyye, Beyrut 1993.

Işıcık, Yusuf, Kur'ân'ı Anlamada Temel İlkeler, Esra Yayınları, Ankara 1997.

İbn Abdürabbih, Ebû Ömer Şihâbüddîn Ahmed, el-İkdu'l-ferîd, thk. Abdulmecîd etTerhînî, Dâru'l-Kütübi'l-İlmiyye. 
İbn Cinnî, Ebu'l-Feth Osmân, el-Hasâis, thk. Muhammed Ali en-Neccâr, elMektebetü'l-İlmiyye, yy. tsz. ,el-Muhteseb fî̀ tebyîni vucûhi şevâzzi'l-kırââti ve'l-îdâhi anhâ, thk. Ali en-

Necdî Nâsıf, Abdulhalîm en-Neccâr, Abdülfettah İsmâîl Şelebî, Dâru Serkîz, yy. 1986.

İbn Fâris, Ebu'l-Hüseyn Ahmed, Mu'cemu mekâyîsi'l-luğa, thk. Abdusselam M. Harun, Dâru'l-Fikr, yy. 1979.

İbn Haldûn, Ebû Zeyd Veliyyüddîn Abdurrahmân, Mukaddimetü İbn Haldûn, thk. Abdullah Muhammed ed-Dervîş, Dâru'l-Belhî, Dımaşk 2004.

İbn Hallikân, Ebu'l-Abbâs Şemsüddîn, Vefeyâtu'l-a'yân ve enbâu ebnâi'z-zamân, thk. İhsan Abbas, Dâru Sâdır, Beyrut 1968.

İbn Hişâm, Ebû Muhammed Cemâlüddîn en-Nahvî, Muğni'l-lebîb an kütübi’l$e$ ‘ârîb, thk. Abdullatîf Muhammed el-Hatîb, es-Silseletü’t-Türâsiyye, yy. tsz.

İbn Mâlik, Ebû Abdillâh Cemâlüddîn Muhammed, Şerhu'l-Kâfiye, thk. Abdulmun'im Ahmed Herîrî, Dâru'l-Menâmûn li’t-Türâs, yy. 1982. , Şerhu't-teshîl, thk. Abdurrahmân es-Seyyid, Muhammed Bedevî el-Mahtûn, Dâru Hicr, yy. tsz.

İbn Manzûr, Ebu'l-Fazl Cemâlüddîn Muhammed b. Mükerrem, Lisânu'l-'Arab, Dâru Sâdır, Beyrut tsz.

İbnu Ebi'l-İz, Ebu'l-Hasen Sadruddîn, Şerhu 'akîdeti't-Tahâviyye, thk. Abdullah b. Abdülmuhsin et-Türkî - Şuayb el-Arnavût, Müessesetü'r-Risâle, yy. tsz.

İbnu'l-Enbâri, Kemaluddîn Abdurrahmân, Nuzhetu'l-elibbâ fî tabakâti'l-udebâ, (nşr. İbrahim Samurâî), Mektebetü'l-Menâr, Ürdün, 1985, s. 18; Şevki Dayf, el-Medârisü'n-nahviyye, Dâru'l-Meârif, Kahire 2008.

İbnü'l-Cezerî, Ebu'l-Hayr Şemsüddin Muhammed, Müncidü'l-mukri'în ve mürşidü't-tâlibîn, Dâru'l-Kütübi'l-İlmiyye, Beyrut 1999.

İbnü'l-Müneyyir, Ebu'l-Abbâs Nâsırüddîn Ahmed, el-İnsâf fî mâ tedammenehü'lKeşşâf (Keşşâf zeylinde), Dâru'l-Kütübi'l-İlmiyye, Beyrut 2015.

İbnü'l-Murtazâ, Mehdî-Lidînillâh Ahmed b. Yahyâ, Tabakâtu'l -Mu 'tezile, Beyrut 1971.

İbnü's-Serrâc, Ebû Bekr Muhammed, el-Usûl fi'n-nahv, thk. Abdulhüseyn el-Fetlî, Müessesetü’r-Risâle, Beyrut 1985.

İnce, Nazife Nihal, Arap Dili İlimleri İle Tecvit İlmi Arasındaki Münasebet, İlâhiyat Yayınları, Ankara 2018.

Kâdî Abdülcebbâr, Fadlu'l- i'tizâl ve tabâkâtü'l- Mu'tezile, nşr. Fuâd Seyyid, Tunus 1393/1974.

Turkish Academic Research Review - Türk Akademik Araştırmalar Dergisi https://dergipark.org.tr/tr/pub/tarr 
Kâdî Abdülcebbâr, Ebu'l-Hasen b. Ahmed el-Hemedânî, Şerhu'l-usûli'l-hamse, thk. Abdulkerim Osman, Mektebetü Vehbe, Kahire 1996. , el-Muğnî fì ebvâbi't-tevhîd ve'l- 'adl, nşr. Emin el-Hûlî, Kahire 1960. , Tenzîhu'l-Kur'ân 'ani'l-metâ 'in, Dâru'l-Kütübi'l-İlmiyye, Beyrut 2008.

Kassâb, Velîd, et-Türâsin-nakdî ve'l-belâgî li'l- Mu'tezile hatta nihâyeti'l-karni'ssâdisi'l-hicrî, Dârü's-Sekâfe, Katar-Doha 1985.

Kaya, Mahmut, "Beytülhikme", TDV İslâm Ansiklopedisi, İstanbul 1992, c. VI, ss. 88-90.

Kazvînî, Ebu'l-Meâlî Celâlüddîn, Telhîsu'l-miftahh, Salah Bilici Kitabevi, İstanbul tsz.

Kızıklı, Zafer, “Arap Dilinde Retoriğin Bir Bilim Dalı Olarak Doğuşu, Gelişimi ve Öncüleri” ICANAS 38 Uluslararası Asya ve Kuzey Afrika Çalışmaları Kongresi Kitabl, Ankara 2007, ss. 1007-1026.

Küçükkalay, Hüseyin, Kur'ân Dili Arapça, Denizkuşları Matbaası, Konya 1969.

Marulcu, Hasan, Ehl-i Sünnet ve Mu'tezile Kelâmı Bağlamında Kelâm - Belâgat İlişkisi, Dilara Yayınları, Isparta 2012.

, Hasan, Kelâm'da Nazar ve Münazara Âdabl, Dilruba Yayınları, Isparta 2018.

Mâtürîdî Ebû Mansûr Muhammed, Te'vîlatü'l-Kur'ân, Mizan Yayınları, İstanbul 2010.

Nasr Hâmid, Ebû Zeyd, Tefsirde Akılcı Eğilim -Mu 'tezile ye Göre Kur'ân'da Mecâz Meselesi-, çev. Numan Konaklı-Nihat Uzun, Mana Yayınları, İstanbul 2015.

Nesefî, Ebu'l-Berekât Hâfizüddîn Abdullah, Medâriku't-tenzîl ve hakâiku't-te'vîl, Dâru İbn Kesîr, Beyrut 2005.

Pişgin, Yasin, “Kur'an'a Göre Akıl-Gayb İlişkisi Bağlamında Mana Yönünde Yönünden Müteşabih Âyetlerin Tevili Meselesi”, Süleyman Demirel Üniversitesi Illahiyat Fakültesi Dergisi, 2012/2, sy. 29, ss. 105-136.

, Kur'an'da Akll ve Tefsirde Akılculı, İlâhiyât Yayınları, Ankara 2015.

Polat, Fethi Ahmet, İslâm Tefsir Geleneğinde Aknlcı Söyleme Yöneltilen Eleştiriler (Mu'tezîlî Zemahşerî’ye Eş'arî İbnü'l-Müneyyir'in Eleştirileri), İz yayınc1lı, İstanbul 2009.

Radî el-Esterâbâdî, Muhammed b. el-Hasen, Şerhu'r-Radî 'ale 'l-Kâfiye, Câmiatu Karyunus, Bingazi 1996.

Râzî, Ebû Abdillâh (Ebu'l-Fazl) Fahrüddîn, Nihâyetü'l-îcâz fì dirâyeti'l-i'câz, thk. Nasrullah Hacımüftüoğlu, Dâru Sâdır, Beyrut 2004. 
, I'tikâdâtu firaki'l-müslimîn ve'l-müşrikîn, nşr. Alî Sâmî en-Neşşâr, Dâru'l-

Kütübi'l-İlmiyye, Beyrut 1982.

, Mefâtîhu'l-ğayb: et-Tefsîru'l-kebîr, Dâru Fikr, Lübnan 1981.

Sabırlı, Esat, Selefí Söylemde Mecaz Karşıtllı̆̆ (İbn Teymiyye'nin Kur'ân'da Mecaza Bakışı Özelinde), Aybil Yay., Konya 2017.

Sekkâkî, Ebû Ya'kûb Sirâcuddîn Yûsuf b. Ebî Bekr, Miftâhu'l-'ulûm, thk. Abdulhamîd Hindâvî, Dâru'l-Kütübi'l-İlmiyye, Lübnan 2014.

Semîn el-Halebî, Ebu'l-Abbâs Şihâbüddîn Ahmed, ed-Dürrü'l-mesûn fì 'ulûmi'lKitâbi'l-meknûn, thk. Ahmed Muhammed el-Harrât, Dâru'l-Kalem, Dımaşk tsz.

Seyf, Muhammed b. Abdillâh, el-Eseru'l- 'akdî fì te 'addüdi't-tevcîhi'l-i 'râbî li âyâti'l-Kur'âni'l-Kerîm, Dâru't-Tedmuriyye, Riyad 2008.

Sîbeveyhi, Ebû Bişr Amr b. Osman, el-Kitâb (Kitâbu Sîbeveyhi), thk. Abdüsselam Muhammed Harun, Mektebetü'l-Hânc1, Kahire tsz.

Suyûtî, Ebu'l-Fazl Celâlüddîn Buğyetü'l-vu 'ât fì tabakâti'l-luğaviyyîn ve'n-nuhât, thk. Muhammed Ebu'l-Fazl İbrâhîm, Dâru'l-Fikr, Beyrut 1979.

, el-İtkân fì 'ulûmi'l-Kur'ân, thk. Şuayb Arnavut, Müessestü'r-Risâle, Beyrut 2008.

, Hem 'ul-hevâmi' fì şerhi Cem 'il-cevâmi', thk. Ahmed Şemsuddîn, Dâru'lKütübi'l-İlmiyye, Beyrut 1998.

Süheylî, Ebu'l-Kâsım Abdurrahmân b. Abdillâh, Netâicü'l-fiker fi'n-Nahv, thk. Ali Muhammed Muavvaz- Âdil Ahmed Abdulmevcûd, Dâru'l-Kütübi'lİlmiyye, Beyrut 1992.

Şehristânî, Ebu'l-Feth Tâcüddîn (Lisânüddîn) Muhammed b. Abdilkerîm, el-Milel ve'n-nihal, nşr. Ahmed Fehmî Muhammed Bağdâdî, Dâru'l-Kütübi'lİlmiyye, Beyrut 1992.

Talâl, Yahyâ İbrâhîm - Nâsıf, Sâmir Abdülcebbâr, "en-Nuhâtü'l-Mu'tezile", Âdâbu'r-Râfideyn, sy. 45, 2007.

Taşdelen, Hasan, "Belâgat İlmi ve Tarihi”, İslâm Medeniyetinde Dil İlimleri-Tarih ve Problemler-, edt. İsmail Güler, İSAM Yayınları, İstanbul 2015, ss. 215-306.

Taşköprizâde, Ahmed b. Mustafa, Miftâhu's-sa'âde ve misbâhu's-siyâde fí mevzu 'âti'l- 'ulûm, Dâru'l-Kütübi'l-İlmiyye, Beyrut 1985.

Teftâzânî, Sa 'düddîn Mes'ûd b. Fahriddîn Muhtasaru'l-me‘ânî, Salah Bilici Kitabevi, İstanbul tsz.

Şerhu'l-'Akâidi'n-Nesefiyye, thk. Ahmet Hicâzî es-Sekkâ, Mektebetü'lKülliyyâti’l-Ezheriyye, Kahire 1987.

Turkish Academic Research Review - Türk Akademik Araştırmalar Dergisi https://dergipark.org.tr/tr/pub/tarr 
Tural, Hüseyin, Arap Edebiyatında Aruz, Ensar Yayınları, İstanbul 2011.

Türcan, Galip, Kelam İlminde Bilgi Kaynağı Olarak Kitâb, İz Yayıncılık, İstanbul 2015.

Ünverdi, Veysi, "Mu'tezile’nin İnanç Sistemi; Usûl-i Hamse/Beş İlke ve Arka Planı”, Artuklu Akademi: Mardin Artuklu Üniversitesi İslâmi Ilimler Fakültesi Dergisi, 2017, c. IV, sy. 2, ss. 1-28.

Versteegh, Kees, Landmarks in Linguistic Thought III, The Arabic Linguistic Tradition, Routledge, Oxon 1997.

Zebîdî, Ebu'l-Feyz Muhammed el-Murtazâ, Tâcu'l- 'arûs min cevâhiri'l-kâmûs, thk. Mahmud Muhammed et-Tanâhî, et-Türâsü'l-Arabî, Kuveyt 1993.

Zehebî, Muhammed Hüseyn, et-Tefsîr ve'l-müfessirûn, Mektebetü Vehbe, Kahire tsz.

Zemahşerî, Ebu'l-Kâsım Mahmûd b. Ömer, Dîvânu Cârillâh ez-Zemahşerî, Dâru Sâdır, Beyrut 2008.

, el-Keşşâf 'an hakâiki ğavâmidı't-tenzîl ve 'uyûni'l-ekâvîl fî̀ vucûhi't-te'vîl,

thk. Muhammed Abdusselâm Şâhîn Dâru'l-Kütübi'l-ilmiyye, Beyrut 2015.

, el-Mufassal fí 'ilmi'l- 'Arabiyye, thk. Fahr Sâlih Kadâra, Ummân 2003.

Zerkeşî, Ebû Abdillâh Bedrüddîn Muhammed, el-Burhân fì 'ulûmi'l-Kur'ân, thk. Muhammed Ebu'l-Fazl İbrâhim, Mektebetü Dâru’t-Turâs, Kahire tsz. 